\title{
Glacier evolution in high-mountain Asia under stratospheric sulfate aerosol injection geoengineering
}

\author{
Liyun Zhao ${ }^{1,2}$, Yi Yang ${ }^{1}$, Wei Cheng ${ }^{1}$, Duoying $\mathbf{J i}^{1,2}$, and John C. Moore ${ }^{1,2,3,4}$ \\ ${ }^{1}$ College of Global Change and Earth System Science, Beijing Normal University, 19 Xinjiekou Wai St., \\ Beijing, 100875, China \\ ${ }^{2}$ Joint Center for Global Change Studies, Beijing, 100875, China \\ ${ }^{3}$ Arctic Centre, University of Lapland, P.O. Box 122, 96101 Rovaniemi, Finland \\ ${ }^{4}$ CAS Center for Excellence in Tibetan Plateau Earth Sciences, Beijing 100101, China \\ Correspondence to: Liyun Zhao (zhaoliyun@bnu.edu.cn) and John C. Moore (john.moore.bnu@gmail.com)
}

Received: 17 September 2016 - Discussion started: 30 September 2016

Revised: 20 April 2017 - Accepted: 21 April 2017 - Published: 2 June 2017

\begin{abstract}
Geoengineering by stratospheric sulfate aerosol injection may help preserve mountain glaciers by reducing summer temperatures. We examine this hypothesis for the glaciers in high-mountain Asia using a glacier mass balance model driven by climate simulations from the Geoengineering Model Intercomparison Project (GeoMIP). The G3 and G4 schemes specify use of stratospheric sulfate aerosols to reduce the radiative forcing under the Representative Concentration Pathway (RCP) 4.5 scenario for the 50 years between 2020 and 2069, and for a further 20 years after termination of geoengineering. We estimate and compare glacier volume loss for every glacier in the region using a glacier model based on surface mass balance parameterization under climate projections from three Earth system models under G3, five models under G4, and six models under RCP4.5 and RCP8.5. The ensemble projections suggest that glacier shrinkage over the period 2010-2069 is equivalent to sea-level rise of $9.0 \pm 1.6 \mathrm{~mm}(\mathrm{G} 3), 9.8 \pm 4.3 \mathrm{~mm}(\mathrm{G} 4)$, $15.5 \pm 2.3 \mathrm{~mm}$ (RCP4.5), and $18.5 \pm 1.7 \mathrm{~mm}$ (RCP8.5). Although G3 keeps the average temperature from increasing in the geoengineering period, G3 only slows glacier shrinkage by about $50 \%$ relative to losses from RCP8.5. Approximately $72 \%$ of glaciated area remains at 2069 under G3, as compared with about $30 \%$ for RCP8.5. The widely reported reduction in mean precipitation expected for solar geoengineering is unlikely to be as important as the temperaturedriven shift from solid to liquid precipitation for forcing Himalayan glacier change. The termination of geoengineering at 2069 under $\mathrm{G} 3$ leads to temperature rise of about $1.3^{\circ} \mathrm{C}$
\end{abstract}

over the period 2070-2089 relative to the period 2050-2069 and corresponding increase in annual mean glacier volume loss rate from 0.17 to $1.1 \% \mathrm{yr}^{-1}$, which is higher than the $0.66 \% \mathrm{yr}^{-1}$ under RCP8.5 during 2070-2089.

\section{Introduction}

High-mountain Asia (HMA) contains the largest number of glaciers outside the polar regions. These glaciers provide water for many large and important rivers (e.g. Brahmaputra, Ganges, Yellow, Yangtze, Indus, and Mekong), and most, but not all, have shrunk over recent decades (Yao et al., 2012). The response of these glaciers to future climate change is a topic of concern especially to the many people who rely on glacier-fed rivers for purposes such as irrigation.

Glacier evolution is expected to be sensitive to climate change. Temperature and precipitation are the important climate factors affecting glaciers. Geoengineering is a method of offsetting the global temperature rise from greenhouse gases, albeit inevitably also altering other important climate parameters, such as precipitation and global atmosphere and ocean circulation teleconnection patterns (Tilmes et al., 2013; Ricke et al., 2010). There have been various studies on mountain glacier change under future-climate scenarios, such as A1B and the various Representative Concentration Pathway (RCP) scenarios (Marzeion et al., 2012; Radić et al., 2014; Zhao et al., 2014). In contrast to glaciers in higher latitudes, many on the Tibetan Plateau are summer accumu- 
lation type (e.g. Fujita and Ageta, 2000); that is, both surface snow fall and melting occur overwhelmingly in the 3 summer months of June, July, and August, with little mass gain or loss throughout the remaining 9 months of the year. However some glaciers, especially in the northwestern parts of HMA, are winter accumulation type (Maussion et al., 2014). Hence, the glaciers are affected by both the South Asian monsoon system and the westerly cyclonic systems, depending on specific location across the region; thus the region integrates the climate response to two important global circulation systems (Mölg et al., 2014).

The impact of geoengineering scenarios on ice sheets and glaciers has been limited to studies on global responses based on semi-empirical models (Moore et al., 2010; Irvine et al., 2012) or on simplified ice sheet responses (Irvine et al., 2009; Applegate and Keller, 2015) or implications of a climate model (McCusker et al., 2015), with nothing to date on mountain glacier impacts.

In this paper, we predict glacier area and volume change for every glacier in HMA under projections from six Earth system model (ESM) simulations of climate under the Geoengineering Model Intercomparison Project (GeoMIP) G3 and G4 scenarios (Kravitz et al., 2011). These scenarios envisage use of stratospheric sulfate aerosols to reduce the radiative forcing under the RCP4.5 greenhouse gas scenario during a 50-year period from 2020 to 2069 followed by sudden cessation of geoengineering to determine the "termination effect" (Jones et al., 2013) but continued RCP4.5 greenhouse gas forcing for a further 20 years. We address two questions here: (1) would glacier shrinkage and loss in HMA be alleviated under geoengineering by stratospheric sulfate aerosol injection? (2) How would the glaciers respond to the termination of geoengineering?

\section{Study region and glacier data}

The Randolph Glacier Inventory (RGI) database contains outlines of almost all glaciers and ice caps outside the two ice sheets (Arendt et al., 2015). Our study region covers HMA $\left(26-46^{\circ} \mathrm{N}, 65-105^{\circ} \mathrm{E}\right)$, which corresponds to the defined regions of Central Asia, South Asia West, and South Asia East in the RGI 5.0. According to the RGI 5.0, the study region contains a total of 94000 glaciers and a glaciered area of about $110000 \mathrm{~km}^{2}$. The RGI 5.0 data inside China are based on the second Chinese glacier inventory (Guo et al., 2015), which provides glacier outlines from 2006 to 2010, except for some older outlines from the first Chinese glacier inventory where suitable imagery could not be found - mainly in southern and eastern Tibet (the S and E Tibet RGI 5.0 subregion), most of which were made in the 1970s. The RGI 5.0 data outside China are from the "Glacier Area Mapping for Discharge from the Asian Mountains" (GAMDAM) inventory (Nuimura et al., 2015), and nearly all come from 19992003, with images selected as close to the year 2000 as possible. Because the data range from each data source is only a few years, we take three reference years -1980 , 2009, and 2000 - as start dates for our model simulations of glaciers in S and E Tibet, elsewhere in China, and outside China, respectively.

Following previous authors (Nuimura et al., 2015; Zhao et al., 2016), we use median altitude from RGI 5.0 for each glacier as a proxy for equilibrium line altitude (ELA) in the respective initial years: that is, the altitude on the glacier where the local net surface mass balance (SMB) is zero. We use the Shuttle Radar Topography Mission (SRTM) version 4.1 (void-filled version; Jarvis et al., 2008) digital elevation model with $90 \mathrm{~m}$ horizontal resolution to estimate the elevation range spanned by each glacier.

Field measurements on SMB are rare in the HMA due to difficulty of access to the glaciers. Following Zhao et al. (2014), we collate SMB versus altitude measurements from 13 glaciers (Table 1 and Fig. 1) to set up parameterizations of mass balance with altitude relative to the ELA for all glaciers.

\section{Methodology}

\subsection{Statistical model of glacier change}

The statistical model for estimating glacier change is based on Zhao et al. $(2014,2016)$. Briefly the algorithm can be described as follows. We start from known glacier outlines from RGI 5.0 and glacier elevation distribution from SRTM 4.1. In the start year, SRTM DEM data ( $90 \mathrm{~m}$ horizontal resolution) inside the glacier outline are interpolated onto a regular grid with a spatial resolution of $10 \mathrm{~m}$ covering the glacier surface. Vertical spacing of altitude bands depends on glacier size, taken as $10 \mathrm{~m}$ for glaciers with a total elevation difference from top to bottom larger than $100 \mathrm{~m}$ and $1 / 10$ of the glacier altitude difference for glaciers with less altitude range.

We parameterize the annual SMB as a function of altitude relative to the ELA for each glacier. We calculate no more than three SMB gradients using in situ SMB measurements for every glacier in Fig. 1 and Table 1. Following Zhao et al. (2014), the SMB-altitude profile is constructed for every glacier by using its own ELA and these SMB gradients. Where SMB data exist in the sub-region, we use them to parameterize the SMB of all glaciers in that sub-region. Otherwise, we use glaciers from nearby sub-regions.

Integrating the SMB over each glacier gives the volume change rate, which is converted to an area change rate using volume-area scaling (Marzeion et al., 2012):

$$
d A(n+1)=\frac{1}{\tau_{\mathrm{A}}}\left(\left(\frac{V(n+1)}{c_{\mathrm{A}}}\right)^{1 / \gamma}-A(n)\right),
$$

where $A(n)$ is glacier area in the $n$th year, $V(n+1)$ is glacier volume and $d A(n+1)$ is area change rate in the $n+1$ th year, 


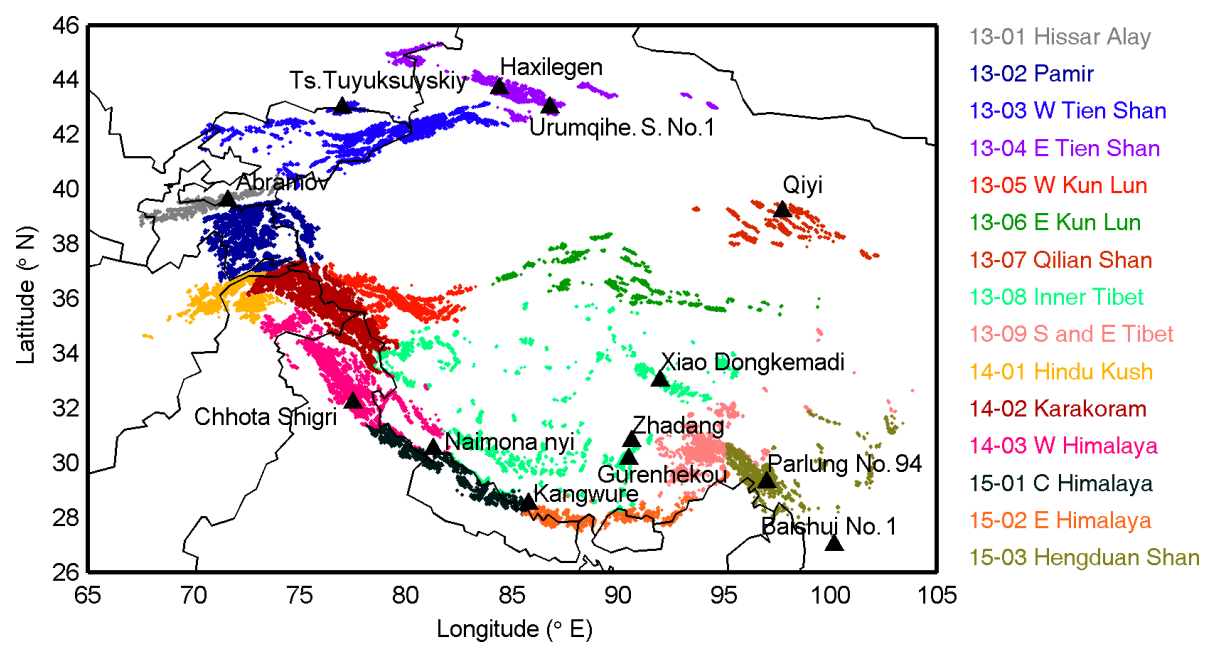

Figure 1. The HMA region analysed. Sub-regions of the HMA in RGI 5.0 are listed and colour-coded in the legend. Glaciers with SMBversus-altitude measurements (Table 1) are marked with black triangles.

$c_{\mathrm{A}}=0.0380 \mathrm{~km}^{3-2 \gamma}$ and $\gamma=1.290$ (Moore et al., 2013), and $\tau_{\mathrm{A}}$ is the response timescale of glacier area and calculated as

$\tau_{\mathrm{A}}(n)=\tau_{\mathrm{L}}(n) \frac{A(n)}{L(n)^{2}}$,

where $L(n)$ and $\tau_{\mathrm{L}}$ are glacier length and the response time scale of glacier length in the $n$th year, respectively. $\tau_{\mathrm{L}}$ is calculated by

$\tau_{\mathrm{L}}(n)=\frac{V(n)}{A(n) \cdot P^{\operatorname{solid}}(n)}$

following the scaling of Johannesson et al. (1989), where $V(n)$ and $P^{\text {solid }}(n)$ denote glacier volume and the solid precipitation on the glacier in the $n$th year, respectively. The initial glacier length $L_{\text {start }}$ is estimated by area-length scaling $A_{\text {start }}=c_{\mathrm{L}} L_{\text {start }}^{q \mathrm{~L}}$, where $c_{\mathrm{L}}=0.0180 \mathrm{~km}^{3-q}$ (Radic et al., 2008) and $q=2.2$ (Bahr et al., 1997). The glacier length change is calculated using the area-length scaling

$d L(n+1)=\frac{1}{\tau_{\mathrm{L}}}\left(\left(\frac{A(n+1)}{c_{\mathrm{L}}}\right)^{1 / q}-L(n)\right)$.

We assume all the area changes take place in the lowest parts of the glacier. The set of glacier surface grid points is updated every year - the number of the grid points that need to be removed or added is calculated using the area change rate, while the elevation of the grid points is updated using SMB.

For retreating glaciers, we remove grid cells near the glacier terminus from the glacier surface grids and get the new glacier terminus position and hence the new outline for the next year. For advancing glaciers, we add grid points to the glacier surface grid, whose elevations are all supposed to be the glacier elevation minimum in the $n+1$ th year, $z_{\min }(n+1)$, which is obtained as follows by assuming a con- stant glacier surface slope,

$z_{\min }(n+1)=z_{\max }(n+1)+\frac{L(n+1)}{L(n)} \cdot\left(z_{\min }(n)-z_{\max }(n)\right)$,

where $z_{\max }(n+1)$ denotes the glacier elevation maximum in the $n+1$ th year. We also limited the maximal surface increase at any point on the glacier to $15 \mathrm{~m}$ above the initial elevation at the starting year. We chose to do this because the valley glacier is physically constrained from growing above the level of the surrounding mountain ridge and side walls.

The SMB-altitude profile on each glacier is evolved annually as the ELA changes, and the ELA evolution is estimated by using its sensitivities with respect to temperature and precipitation as follows:

$\mathrm{ELA}_{n}=\mathrm{ELA}_{n-1}+\alpha \Delta T+\beta \Delta P$,

where $\mathrm{ELA}_{n}$ is the ELA in the $n$th year from the beginning year; $\Delta T$ and $\Delta P$ are the inter-annual change of summertime (June-July-August) mean air temperature and annual solid precipitation on the glacier, respectively; and the coefficients $\alpha$ (unit: $\mathrm{m}^{\circ} \mathrm{C}^{-1}$ ) and $\beta$ (unit: $\mathrm{m} \mathrm{m}^{-1}$ ) are the sensitivity of ELA shift to air temperature change $\left({ }^{\circ} \mathrm{C}\right)$ and precipitation change $(\mathrm{m})$, respectively, which are zonal mean values from energy-balance modelling of glaciers in HMA by Rupper and Roe (2008) (see also Zhao et al., 2014).

\subsection{Climate scenarios and downscaling of climate data}

We run the simulations for glacier change from the relevant start years (Sect. 2) to the year 2089. From the start years to 2013 , we use the relatively high resolution monthly-mean gridded $0.5^{\circ} \times 0.5^{\circ}$ temperature data from the Climatic Research Unit Time-Series (CRU TS) 3.24 dataset (Harris et al., 2014) and $0.5^{\circ} \times 0.5^{\circ}$ monthly total gridded precipitation data from the Global Precipitation Climatology Centre (GPCC) Total Full V7 dataset (Becker et al., 2013). 
Table 1. The benchmark glaciers; their RGI 5.0 sub-regions; and their exact location (Fig. 1), altitude range, averaged SMB gradients (unit: $\mathrm{m} \mathrm{m}^{-1}$ ) in specific altitude intervals, and ELA and SMB data sources.

\begin{tabular}{|c|c|c|c|c|c|}
\hline $\begin{array}{l}\text { Glacier name and } \\
\text { sub-region }\end{array}$ & Location & $\begin{array}{l}\text { Altitude } \\
\text { range }(\mathrm{m})\end{array}$ & $\begin{array}{l}\text { Averaged SMB } \\
\text { gradients }\end{array}$ & $\begin{array}{l}\text { Period of SMB } \\
\text { measurements }\end{array}$ & Reference \\
\hline $\begin{array}{l}\text { Abramov Glacier } \\
(13-01)\end{array}$ & $\begin{array}{l}\left(39^{\circ} 38^{\prime} \mathrm{N}\right. \\
\left.71^{\circ} 36^{\prime} \mathrm{E}\right)\end{array}$ & $3600-4700$ & $\begin{array}{l}0, z>\text { ELA }+200 \\
0.0088, z<\text { ELA }+200 \\
\text { ELA varies in } 4050-4450\end{array}$ & 1987-1997 & $\begin{array}{l}\text { WGMS } \\
(1991,1993,1994, \\
1996,1999,2001)\end{array}$ \\
\hline $\begin{array}{l}\text { Ts. Tuyuksuyskiy } \\
\text { Glacier (13-03) }\end{array}$ & $\begin{array}{l}\left(43^{\circ} 03^{\prime} \mathrm{N}\right. \\
\left.77^{\circ} 05^{\prime} \mathrm{E}\right)\end{array}$ & $3400-4200$ & $\begin{array}{l}0, z>\text { ELA + 100; } \\
0.0057, z<\text { ELA + 100; } \\
\text { ELA varies in 3600-4200 }\end{array}$ & $1987-2011$ & $\begin{array}{l}\text { WGMS } \\
(1991,1993,1994,1996, \\
1999,2001,2003,2005, \\
2007,2009,2011,2013)\end{array}$ \\
\hline $\begin{array}{l}\text { Urumqihe S. No. } 1 \\
\text { Glacier (13-04) } \\
\text { (East branch) }\end{array}$ & $\begin{array}{l}\left(43^{\circ} 06^{\prime} \mathrm{N}\right. \\
\left.86^{\circ} 49^{\prime} \mathrm{E}\right)\end{array}$ & $3700-4300$ & $\begin{array}{l}0.002 \\
\text { ELA }<z<4300 \\
0.01, z<\text { ELA; } \\
\text { ELA varies in } 3950-4175\end{array}$ & $1987-2011$ & $\begin{array}{l}\text { WGMS } \\
(1991,1993,1994,1996, \\
1999,2001,2003,2005, \\
2007,2009,2011,2013)\end{array}$ \\
\hline $\begin{array}{l}\text { Haxilegen No. } 51 \\
\text { Glacier (13-04) }\end{array}$ & $\begin{array}{l}84^{\circ} 24^{\prime} \mathrm{E} \\
43^{\circ} 43^{\prime} \mathrm{N}\end{array}$ & $3475-3700$ & 0.012 & 1999-2005 & Zhang et al. (2015) \\
\hline $\begin{array}{l}\text { Qiyi Glacier } \\
(13-07)\end{array}$ & $\begin{array}{l}\left(39^{\circ} 14^{\prime} \mathrm{N}\right. \\
\left.97^{\circ} 45^{\prime} \mathrm{E}\right)\end{array}$ & $4310-5145$ & $\begin{array}{l}0.0042 \\
4800<z<\mathrm{ELA} \\
0.0014, z<4800 \\
\text { where ELA }=5012\end{array}$ & $\begin{array}{l}\text { Jun-Sep 2002; } \\
\text { 2002-2003; } 2010\end{array}$ & $\begin{array}{l}\text { Pu et al. (2005); } \\
\text { Wang et al. (2011) }\end{array}$ \\
\hline $\begin{array}{l}\text { Zhadang Glacier } \\
(13-08)\end{array}$ & $\begin{array}{l}\left(30^{\circ} 28^{\prime} \mathrm{N}\right. \\
\left.90^{\circ} 38^{\prime} \mathrm{E}\right)\end{array}$ & $5515-6090$ & 0.0041 & $\begin{array}{l}\text { 2005-2006; } \\
\text { Jun-Jul 2009; } \\
\text { Sep 2009-May 2010; } \\
\text { Aug-Sep } 2010\end{array}$ & $\begin{array}{l}\text { Zhou et al. (2007), } \\
\text { Mölg et al. (2012) } \\
\text { Yu et al. (2013) }\end{array}$ \\
\hline $\begin{array}{l}\text { Gurenhekou } \\
\text { Glacier (13-08) }\end{array}$ & $\begin{array}{l}\left(30^{\circ} 11^{\prime} \mathrm{N}\right. \\
\left.90^{\circ} 27^{\prime} \mathrm{E}\right)\end{array}$ & $5550-6020$ & 0.0041 & 2004-2008 & Yu et al. (2013) \\
\hline $\begin{array}{l}\text { Xiao Dongkemadi } \\
\text { Glacier (13-08) }\end{array}$ & $\begin{array}{l}\left(33^{\circ} 04^{\prime} \mathrm{N}\right. \\
\left.92^{\circ} 05^{\prime} \mathrm{E}\right)\end{array}$ & $5380-5926$ & $\begin{array}{l}0.007, z<\text { ELA; } \\
0.004, \text { ELA }<z<5750 \\
\text { where ELA } \sim=5515\end{array}$ & $2008-2012$ & Zhang et al. (2013) \\
\hline $\begin{array}{l}\text { Chhota Shigri } \\
\text { Glacier (14-03) }\end{array}$ & $\begin{array}{l}\left(32^{\circ} 12^{\prime} \mathrm{N}\right. \\
\left.77^{\circ} 30^{\prime} \mathrm{E}\right)\end{array}$ & $4000-5600$ & $\begin{array}{l}0.003, \text { ELA }<z<5600 \\
0.01 \\
\text { ELA }-150<z<\text { ELA; } \\
0.005 \\
4000<z<\text { ELA }-150 \\
\text { where ELA varies in } 4855-5180\end{array}$ & $\begin{array}{l}\text { Annual average } \\
\text { SMB during } \\
\text { 2002-2010; } \\
\text { 2003-2004; } \\
\text { 2004-2005 }\end{array}$ & $\begin{array}{l}\text { Azam et al. (2012); } \\
\text { Wagnon et al. } \\
(2007)\end{array}$ \\
\hline $\begin{array}{l}\text { Naimona'nyi } \\
\text { Glacier (15-01) }\end{array}$ & $\begin{array}{l}\left(30^{\circ} 27^{\prime} \mathrm{N}\right. \\
\left.81^{\circ} 20^{\prime} \mathrm{E}\right)\end{array}$ & $5600-6150$ & $\begin{array}{l}0.0006, z>\text { ELA; } \\
0.0038,5700<z<\text { ELA; } \\
\text { where ELA } \sim=6100\end{array}$ & $2005-2010$ & Yao et al. (2012) \\
\hline $\begin{array}{l}\text { Kangwure Glacier } \\
(15-01)\end{array}$ & $\begin{array}{l}\left(28^{\circ} 28^{\prime} \mathrm{N}\right. \\
\left.85^{\circ} 49^{\prime} \mathrm{E}\right)\end{array}$ & $5700-6100$ & $0.0038,5700<z<6100$ & $2005-2010$ & Yao et al. (2012) \\
\hline $\begin{array}{l}\text { Parlung No. } 94 \\
\text { Glacier (15-03) }\end{array}$ & $\begin{array}{l}\left(29^{\circ} 20^{\prime} \mathrm{N}\right. \\
\left.97^{\circ} 0^{\prime} \mathrm{E}\right)\end{array}$ & $5067-5334$ & 0.01 & 2006-2010 & Yang et al. (2013b) \\
\hline $\begin{array}{l}\text { Baishui No. } 1 \\
\text { Glacier (15-03) }\end{array}$ & $\begin{array}{l}26^{\circ} 59^{\prime}- \\
27^{\circ} 17^{\prime} \mathrm{N} \\
100^{\circ} 04^{\prime}- \\
100^{\circ} 15^{\prime} \mathrm{E}\end{array}$ & $4300-5000$ & $\begin{array}{l}0.003, z>\text { ELA; } \\
0.01 \\
\text { ELA }-250<z<\text { ELA; } \\
0.0035 \\
4300<z<4650 \\
\text { where ELA }=4972\end{array}$ & $2008-2009$ & Du et al. (2013) \\
\hline
\end{tabular}


Table 2. Summer mean temperature $(\Delta T)$ and annual solid-precipitation $(\Delta P)$ anomalies over 2030-2069 for each model and scenario in the glaciated region of high-mountain Asia relative to their RCP4.5 2010-2029 values.

\begin{tabular}{|c|c|c|c|c|c|c|c|c|}
\hline \multirow[b]{2}{*}{ Model/scenarios } & \multicolumn{4}{|c|}{$\Delta T\left({ }^{\circ} \mathrm{C}\right)$} & \multicolumn{4}{|c|}{$\Delta P\left(\mathrm{~mm} \mathrm{yr}^{-1}\right)$} \\
\hline & G3 & G4 & $\mathrm{RCP} 4.5$ & RCP8.5 & G3 & G4 & $\mathrm{RCP} 4.5$ & RCP8.5 \\
\hline BNU-ESM & -0.26 & -0.15 & 1.06 & 1.77 & 3.6 & 9.4 & -53.6 & -84.7 \\
\hline CanESM2 & & 0.67 & 1.48 & 2.27 & -29.2 & -19.6 & -43.0 & \\
\hline HadGEM2-ES & 0.48 & 0.10 & 1.09 & 1.71 & -10.3 & 0.2 & -19.0 & -45.7 \\
\hline IPSL-CM5A-LR & 0.32 & & 1.44 & 2.18 & -16.8 & & -50.1 & -72.0 \\
\hline MIROC-ESM & & 0.76 & 1.30 & 1.99 & & -29.2 & -51.6 & -64.2 \\
\hline MIROC-ESM-CHEM & & 0.97 & 1.29 & 2.23 & & -19.6 & -30.3 & -66.5 \\
\hline
\end{tabular}

Table 3. Climate models and datasets used in this study.

\begin{tabular}{llrl}
\hline Name & Reference & Resolution & Datasets \\
\hline CRU & Harris et al. (2014) & $0.5^{\circ} \times 0.5^{\circ}$ & Surface temperature 1980-2013 \\
GPCC & Becker et al. (2013) & $0.5^{\circ} \times 0.5^{\circ}$ & Precipitation 1980-2013 \\
BNU-ESM & Ji et al. (2014) & $2.8^{\circ} \times 2.8^{\circ}$ & G3, G4, RCP4.5, RCP8.5 \\
CanESM2 & Arora et al. (2011) & $2.8^{\circ} \times 2.8^{\circ}$ & G4, RCP4.5, RCP8.5 \\
HadGEM2-ES & Collins et al. (2011) & $1^{\circ} \times 1.9^{\circ}$ & G3, G4, RCP4.5, RCP8.5 \\
IPSL-CM5A-LR & Dufresne et al. (2013) & $1.9^{\circ} \times 3.8^{\circ}$ & G3, RCP4.5, RCP8.5 \\
MIROC-ESM & Watanabe et al. (2011) & $2.8^{\circ} \times 2.8^{\circ}$ & G4, RCP4.5, RCP8.5 \\
MIROC-ESM-CHEM & Watanabe et al. (2011) & $2.8^{\circ} \times 2.8^{\circ}$ & G4, RCP4.5, RCP8.5 \\
\hline
\end{tabular}

For the years 2014 to 2089 we use four kinds of climate forcing: experiment RCP4.5 and RCP8.5, and results from two GeoMIP scenarios (G3 and G4; Kravitz et al., 2011) which use stratospheric aerosols to reduce the incoming shortwave while applying the RCP4.5 greenhouse gas forcing. In G3 and G4, stratospheric geoengineering of sulfate aerosol injection starts in the year 2020 and ends in the year 2069. In the 50 years of geoengineering, G3 is designed to achieve a balance between reduction of incoming shortwave radiation and the increase in greenhouse gas forcing, while $\mathrm{G} 4$ specifies continuous injection of $\mathrm{SO}_{2}$ into the equatorial lower stratosphere at a rate of $5 \mathrm{Tg}$ per year from 2020. The across-model spread of temperatures under G4 is larger than under, for example, RCP4.5 (Table 2; there are too few ensemble member models under G3 to see this) because of differences in how the aerosol forcing is handled, and each model has a different temperature response to the combined long- and shortwave forcing (Yu et al., 2015). Following the abrupt end of geoengineering, both G3 and G4 specify 20 years of further simulation from 2070 to 2089.

We derived climate forcing data from three climate models participating in G3, five models in G4, and six models in RCP4.5 and RCP8.5 (Table 3). We use the Coupled Model Intercomparison Project Phase 5 (CMIP5; Taylor et al., 2012) output of all models. Yu et al. (2015) noted there was no significant change in surface temperatures after sulfate aerosol was injected in the GISS-E2-R model, possibly due to the efficacy of $\mathrm{SO}_{2}$ forcing being relatively small as compared to $\mathrm{CO}_{2}$ forcing in the model. We do not find a termination ef- fect in GISS-E2-R under G3 either. Therefore, we not use any results from GISS-E2-R. We also exclude the model CISRO$\mathrm{Mk} 3 \mathrm{~L}$ due to its very coarse spatial resolution of about $4^{\circ}$ and the absence of simulation results in the year 2020 under G4; the models used and their resolutions are listed in Table 3.

Compared with the size of most glaciers in HMA (typically kilometre scale), the CRU, GPCC, and climate model grids have rather coarse resolution (Table 3 ). The direct use of coarse grid points naturally results in a poor representation of the local climate. Hence we downscale the CRU gridded temperature data, the GPCC gridded precipitation data, and the climate model output to a grid based on a land surface topography having resolution of $0.1126^{\circ} \times 0.1126^{\circ}$ (Gao et al., 2012) using an altitude temperature lapse rate of $0.65^{\circ} 100 \mathrm{~m}^{-1}$, an altitude precipitation lapse rate of $3 \% 100 \mathrm{~m}^{-1}$ (Marzeion et al., 2012), and elevation difference of the fine local grid point relative to the climate model grid.

We bias-correct the downscaled model temperatures and precipitation output by using CRU gridded temperature data and GPCC gridded precipitation data as a reference climate. Downscaled series were produced for each climate model for the period 2013 to 2089 under each climate scenario by averaged monthly differences over the baseline period 1980 to 2005 taken from the models' CMIP5 historical simulations. We only use summer (JJA) mean near-surface air temperature. Therefore, future temperature time series $T_{i}(t)$ on 
each grid point were calculated by

$T_{i}(t)=T_{i, \mathrm{c}}(t)+\left(\bar{T}_{i, \mathrm{CRU}}-\bar{T}_{i, \mathrm{c}, \text { history }}\right), i=6,7,8$,

where $T_{i, \mathrm{c}}(t)$ is monthly-mean temperature for the $i$ th month from the climate model output from $t=2013$ to 2089, and

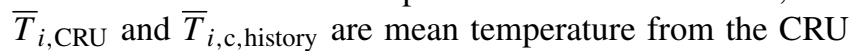
TS V3.24 dataset and climate model output, respectively, for the $i$ th month averaged over the baseline period 1980-2005 on each grid point.

Future precipitation time series $P_{i}(t)$ on each grid point were calculated by

$P_{i}(t)=P_{i, \mathrm{c}}(t) \cdot \frac{\bar{P}_{i, \mathrm{GPCC}}}{\bar{P}_{i, \mathrm{c}, \text { history }}}, i=1, \ldots, 12$,

where $P_{i, \mathrm{c}}(t)$ is monthly precipitation for the $i$ th month from the climate model output from $t=2013$ to 2089, and

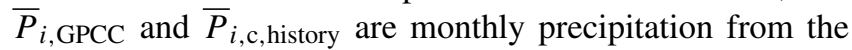
GPCC dataset and climate model output, respectively, for the $i$ th month averaged over the baseline period 1980-2005 on each grid point.

The temperature and precipitation on each glacier were calculated by an altitude temperature lapse rate of $0.65^{\circ} 100 \mathrm{~m}^{-1}$, precipitation lapse rate of $3 \% 100 \mathrm{~m}^{-1}$ (Marzeion et al., 2012), and the elevation difference of the glacier surface elevation relative to the nearest fine grid point. Moreover, the solid precipitation on the glacier is calculated by the fraction of solid precipitation, $f_{\text {solid, }}$ based on the monthly-mean temperature $T_{\mathrm{a}}$ on the glacier as (Fujita and Nuimura, 2011)

$f_{\text {solid }}= \begin{cases}1, & \text { if } T_{\mathrm{a}} \leq 0^{\circ} \mathrm{C} \\ 1-\frac{T_{\mathrm{a}}}{4}, & \text { if } 0<T_{\mathrm{a}}<4{ }^{\circ} \mathrm{C} . \\ 0, & \text { if } T_{\mathrm{a}} \geq 4{ }^{\circ} \mathrm{C}\end{cases}$

\subsection{Validation of the glacier model and methodology}

In this section we justify the selection of various parameter values used in the method here. In Sect. 5 we indicate how elements in the model and climate forcing affect the uncertainties of the results we produce in Sect. 4, and how those results compare with previous estimates of glacier evolution in HMA.

A crucial parameterization concerns the SMB-altitude gradients. The field data (Table 1) include three more glaciers than those used in Zhao et al. $(2014,2016)$ and include a benchmark glacier from almost every sub-region. With so few glacier observations available, there is an issue of how representative they are of the general population. For inner Tibet, there are three glaciers (Zhadang, Gurenhekou, and Xiao Dongkemadi glaciers) with SMB observations, and they have almost the same SMB-altitude gradients, $0.0041 \mathrm{~m} \mathrm{~m}^{-1}$, over their common elevation range (5515$5750 \mathrm{~m}$, Table 1); two glaciers (Naimona'nyi and Kangwure) in central Himalaya (C Himalaya) have SMB gradients of $0.0038 \mathrm{~m} \mathrm{~m}^{-1}$ in their common altitude range of $5700-$ $6100 \mathrm{~m}$. These similarities suggest that the measured glaciers share some important characteristics with the vast majority which are not surveyed.

Next we consider the choices for the initial value of ELA at the start year, different $\mathrm{V}-\mathrm{A}$ scaling parameters, and different ELA sensitivities to summer mean temperature and annual precipitation.

In choosing the initial ELAs for each glacier, there are several reasonable alternatives (Zhao et al., 2016): (i) using ELAs interpolated from the first Chinese glacier inventory, (ii) using median elevations from the RGI dataset, and (iii) using the elevation of the 60th percentile of the cumulative area above the glacier terminus. Zhao et al. (2016) showed that these three choices lead to a range of about $2.5 \mathrm{~mm}$ of global sea level in glacier volume loss by 2050. In this study, we use median elevations from the RGI dataset, which corresponds to the median result.

Zhao et al. (2014) showed that different volume-area scaling parameterizations can lead to a $\pm 5 \%$ range of glacier volume loss. The set of parameters we use in this study corresponds to the lower bound of estimated volume loss, but one that is best matched to the observational dataset of 230 separate glaciers (Moore et al., 2013).

For the ELA sensitivity to summer mean temperature and annual precipitation, we use the zonal mean values from energy-balance modelling of glaciers in HMA by Rupper and Roe (2008). Alternatively, it can be estimated using an empirical formula for ablation and a degree-day method (Zhao et al., 2016). Zhao et al. (2016) calculated the ELA for nine glaciers in China, India, and Kyrgyzstan, and compared them with the observed ELA time series by similarities of decadal trends and also annual variability. The Rupper and Roe ELA parameterization produced the best fits to observed ELA decadal trends on nine glaciers, with a correlation coefficient of 0.6 , which is significant ( $p<0.05$; the values we give for $p$ are single-tailed Pearson correlation tests).

Combining the above uncertainties would require a Monte Carlo simulation since the parameters combine non-linearly to produce glacier volume and area change; this is prohibitively expensive to perform given that a single simulation of all glaciers in HMA requires about $60 \mathrm{CPU}$ hours on an eight cores computer with parallel computing in Matlab. We did estimate elevation changes for individual glaciers directly from simulated volume and area changes; then we calculated the average rate of elevation change for all the glaciers in each sub-region and compared them with remote-sensing estimates from 2003 to 2009 from Gardner et al. (2013) (Table 4). The correlation coefficient between the Gardner et al. (2013) estimates for the 6 RGI 5.0 sub-regions with regional data and our modelled regional averages is 0.7 , which is marginally significant $(p<0.1)$.

In our simulations we have used constant lapse rates for temperature $\left(0.65^{\circ} 100 \mathrm{~m}^{-1}\right)$ and precipitation $\left(3 \% 100 \mathrm{~m}^{-1}\right)$. To check how reliable this is, we chose five 
Table 4. The average rate of elevation change $\left(\mathrm{myr}^{-1}\right)$ for all the glaciers in sub-regions compared with remote-sensing estimates from 2003 to 2009 from Gardner et al. (2013).

\begin{tabular}{lcr}
\hline Sub-regions & Gardner et al. (2013) & Modelled \\
\hline Hissar Alay and Pamir & $-0.13 \pm 0.22$ & $-0.02 \pm 0.49$ \\
S and E Tibet & $-0.30 \pm 0.13$ & $-0.39 \pm 0.75$ \\
Hindu Kush and Karakoram & $-0.12 \pm 0.15$ & $-0.08 \pm 0.29$ \\
W Himalaya & $-0.53 \pm 0.13$ & $0.32 \pm 0.29$ \\
C Himalaya & $-0.44 \pm 0.20$ & $-0.62 \pm 0.63$ \\
E Himalaya & $-0.89 \pm 0.18$ & $-1.51 \pm 0.59$ \\
\hline All HMA & $-0.27 \pm 0.17$ & $-0.13 \pm 0.60$ \\
\hline
\end{tabular}

meteorological stations close to glaciers and calculated correlation coefficients for JJA temperature and annual precipitation at the station and at the nearest downscaled grid point from 1980 to $2013(n=34)$. Precipitation correlations were higher than 0.85 for all the stations $(p<0.001)$, while temperatures correlations were $0.47-0.85(p<0.01)$.

\section{Results}

\subsection{Climate and glacier change across HMA}

\subsubsection{Temperature and precipitation over HMA}

We construct the climate forcing by using CRU temperature data and GPCC precipitation data before 2013; climate models (Table 3) with model bias correction (Sect. 3.2) under RCP4.5 from 2014 to 2019; and climate models with model bias correction under climate scenarios G3, G4, RCP4.5, and RCP8.5 from the year 2020 to 2089. The JJA mean temperature projections in the whole region under G3, G4, RCP4.5, and RCP8.5 from 2020 to 2089 are shown in Fig. 2. Figure 3 shows the time series of JJA mean temperature and annual precipitation forcing from the beginning years to 2089, with the across-model range from the ensemble members; ranges found are slightly smaller than the regional spread found by Yu et al. (2015) due to the grid-point-by-grid-point bias correction we apply here.

The multi-model mean temperature under G4 is higher than that under G3 in the geoengineering period. In contrast with the ensemble mean temperature, the HMA mean temperature projected by HadGEM2-ES under G4 is cooler than that under G3, and its G4 temperature is lower than the ensemble mean, while its $\mathrm{G} 3$ is higher than the ensemble mean (Fig. 2). The across-model spread in temperature response to G4 is larger than that under G3. Temperatures projected by BNU-ESM are lower than the ensemble mean under both G3 and G4.

The temperature averages over the whole region and the glaciated parts have similar trends. Temperatures under RCP8.5, as expected, increase at the highest linear rate among all the scenarios. Temperature rise under RCP4.5 is the next highest, and its rate becomes smaller after about the year 2050 as specified greenhouse gas emissions decline. There is relative cooling of $1.05^{\circ} \mathrm{C}$ under $\mathrm{G} 3$ and $0.76^{\circ} \mathrm{C}$ under G4 as compared with RCP4.5 during 2020-2069 across the whole region (Fig. 3). Yu et al. (2015) noted that G3 produced relative cooling under $\mathrm{G} 3$ of $0.58^{\circ} \mathrm{C}$ and under $\mathrm{G} 4$ of $0.53^{\circ} \mathrm{C}$ in globally averaged temperature over the 2030 2069 period.

There is no trend in temperature under G3 over the geoengineering period (2020-2069). But after the termination in the year 2069 , there is a temperature rise of about $1.3^{\circ} \mathrm{C}$ over the period 2070-2089 relative to the period 2050-2069 under G3. There is a less obvious termination rise of temperature under G4 than under G3. This is due to G4 having a constant stratospheric aerosol injection rate of $5 \mathrm{Tg} \mathrm{SO}_{2} \mathrm{yr}^{-1}$, while $\mathrm{G} 3$ gradual ramps up the aerosol so that about twice as much is needed by 2069, depending upon the sensitivity of the particular model to stratospheric sulfate aerosols. Hence, the radiative impact of terminating G3 is about twice as large as terminating $\mathrm{G} 4$, and the termination temperature signal is much more obvious in G3 than G4.

The annual precipitation averages over the whole region do not show obvious trends in any climate scenarios (Fig. 3c). However, the annual solid-precipitation averages over the glaciers show decreasing trends in all the scenarios (Fig. 3d) until 2070, which is due to increases in surface air temperature (Fig. 3b). Under RCP8.5, annual solid precipitation averaged over each glacier decreases fastest $\left(2.2 \mathrm{~mm} \mathrm{yr}^{-1}\right)$. Decreases are similar (about $1.5 \mathrm{~mm} \mathrm{yr}^{-1}$ ) under RCP4.5 and G4 and least $\left(0.3 \mathrm{~mm} \mathrm{yr}^{-1}\right)$ under $\mathrm{G} 3$ during the geoengineering period (2020-2069). After the year 2070, there are no trends in annual solid precipitation under G3, G4, and RCP4.5 (Fig. 3d) due to stable temperatures (Fig. 3b).

\subsubsection{Glacier changes across HMA}

Glacier volume changes for all the glaciers in the study region computed using temperature and precipitation data from the four scenarios are shown in Fig. 4a. The uncertainty we plot is due only to the differences between climate forcing across the models; it does not reflect uncertainty of the glacier model parameters. Volume loss rates increase in the following order, from lowest to highest, for the period 2020 2069: G3, G4, RCP4.5, RCP8.5. The RCP4.5 and RCP8.5 scenarios produce similar continuous mass loss until approximately 2035 (Fig. 4a) mainly due to the similarity of temperatures projected by RCP4.5 and RCP8.5 in the period 2020 2035 (Fig. 3a), and both show relatively slower loss rates after about the year 2050 probably because the most sensitive glaciers have already retreated before 2050 . The multi-model mean glacier volume loss in equivalent to sea-level rise for the whole study region from 2010 to the end of geoengineering in 2069 is $9.0 \mathrm{~mm}$ (G3), $9.8 \mathrm{~mm}$ (G4), $15.5 \mathrm{~mm}$ (RCP4.5), and $18.5 \mathrm{~mm}$ (RCP8.5), with 91.8, 96.0, 98.5, and $99.7 \%$ of glaciers retreating under these scenarios (Table 5). Volume 


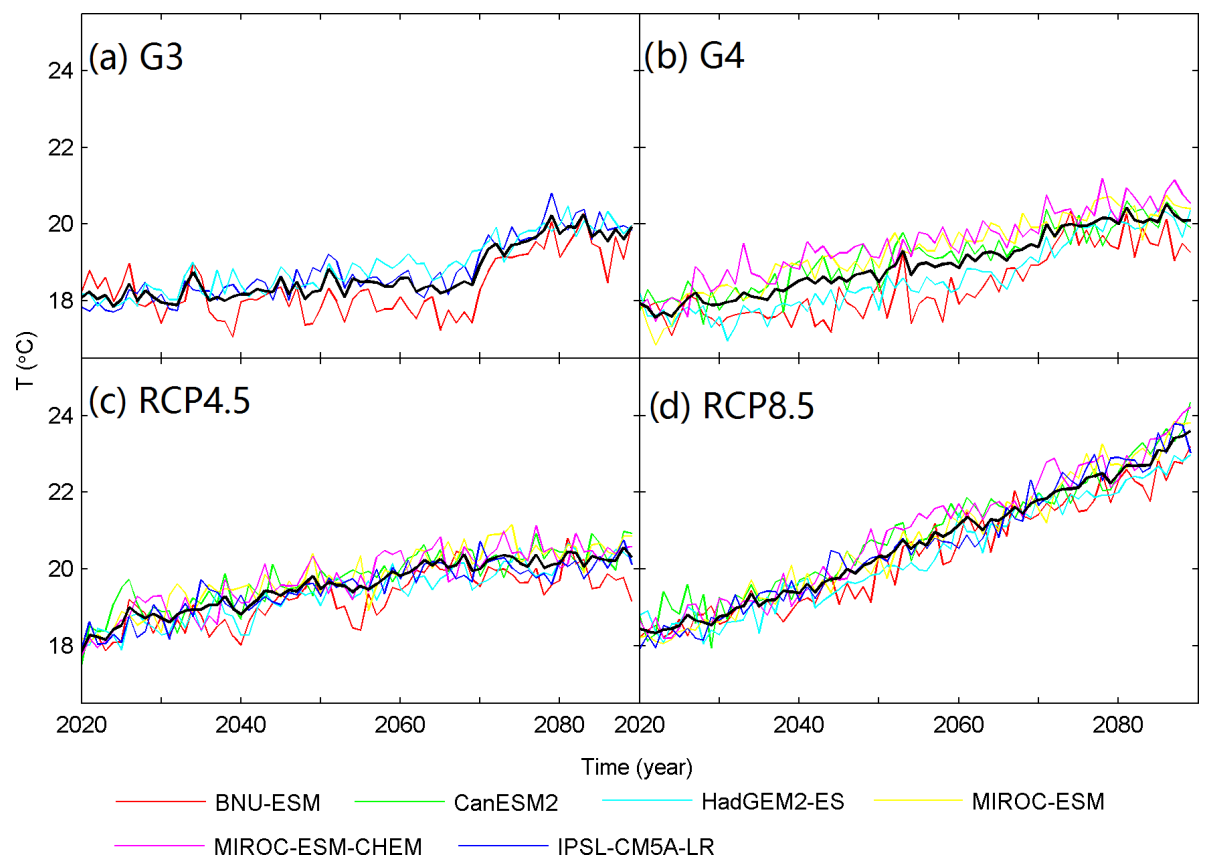

Figure 2. Time series of summer mean bias-corrected temperature averaged over the downscaled grid in the whole HMA region projected by ensemble members under climate scenarios G3 (a), G4 (b), RCP4.5 (c), and RCP8.5 (d). Black curve in each plot is the mean of the relevant ensemble (Table 3).
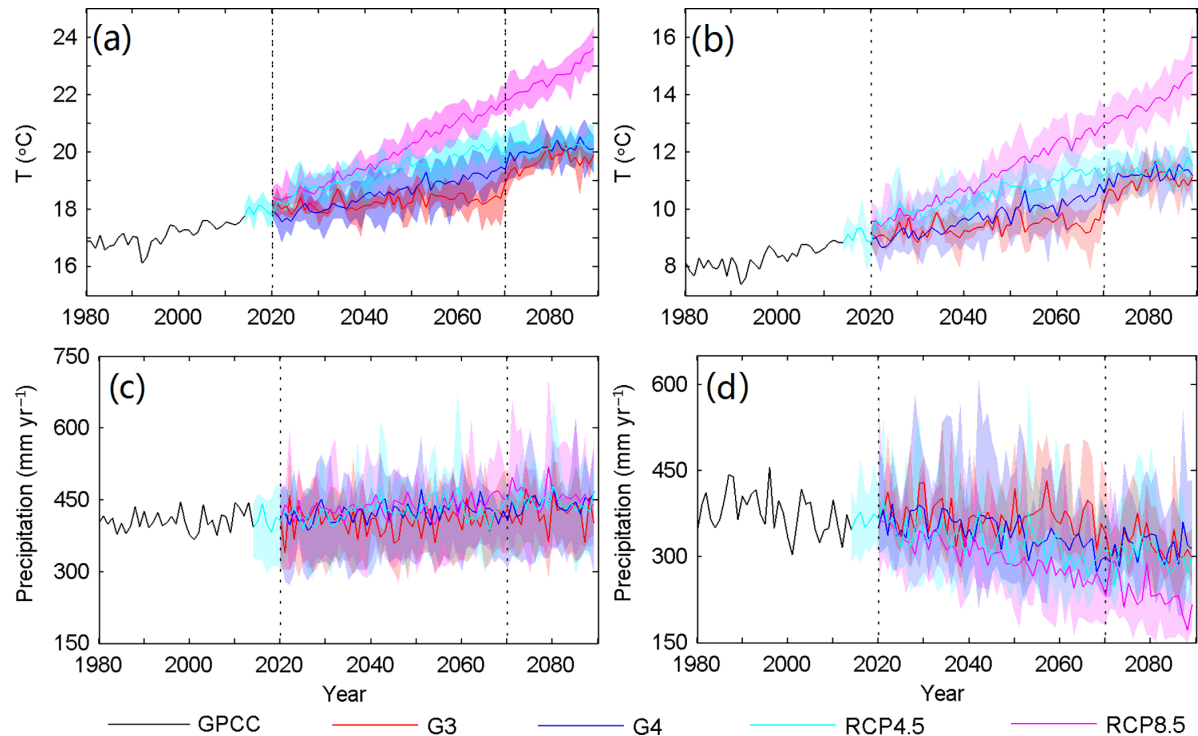

Figure 3. Time series of summer mean bias-corrected temperature (a, b) and annual precipitation (c, $\mathbf{d})$ averaged over the downscaled grid (Sect. 3.2) in the whole region (a, c) and only in the glaciated region $(\mathbf{b}, \mathbf{d})$. Note the different temperature ranges in $(\mathbf{a}, \mathbf{b})$ and precipitation ranges in (c, d). Precipitation in (d) is the average annual solid precipitation at the ELA of each glacier in the start year of simulations, which is taken here to be representative of each glacier. The solid curves and shadings from 2013 to 2089 are the ensemble mean and the across-model spread between ensemble members for each scenario, respectively, which are colour-coded in the legend.

loss using the climate projected by HadGEM2-ES under G4 is far less than that by other models (Table 5), this produces a larger standard deviation for the results than for other scenarios in Table 5. The cause is the combination of small precip- itation decrease under RCP4.5 and the G4 anomaly, accompanied by only modest warming (Table 2 ). These numbers may also be compared with the simulations run using the ensemble mean climate forcing (last row in Table 5), which are 
Table 5. The volume loss in millimetre sea-level equivalent, projected using forcing from all the climate models in the period 2010-2069 and the post-geoengineering period 2070-2089 under G3, G4, RCP4.5, and RCP8.5. The means of volumes lost driven by individual model forcing and its standard deviation are shown in the penultimate row. The simulated volume loss using the climate model ensemble mean forcing of temperature and precipitation is shown in the last row. The volume loss is calculated by assuming ice density of $900 \mathrm{~kg} \mathrm{~m}^{-3}$ and ocean area of $362 \times 10^{12} \mathrm{~m}^{2}$.

\begin{tabular}{|c|c|c|c|c|c|c|c|c|}
\hline \multirow{2}{*}{$\begin{array}{l}\text { Scenarios } \\
\text { Period/ } \\
\text { model }\end{array}$} & \multicolumn{2}{|c|}{ G3 } & \multicolumn{2}{|c|}{ G4 } & \multicolumn{2}{|c|}{$\mathrm{RCP} 4.5$} & \multicolumn{2}{|c|}{ RCP8.5 } \\
\hline & $\begin{array}{r}2010- \\
2069\end{array}$ & $\begin{array}{r}2070- \\
2089\end{array}$ & $\begin{array}{r}2010- \\
2069\end{array}$ & $\begin{array}{r}2070- \\
2089\end{array}$ & $\begin{array}{r}2010- \\
2069\end{array}$ & $\begin{array}{r}2070- \\
2089\end{array}$ & $\begin{array}{r}2010- \\
2069\end{array}$ & $\begin{array}{r}2070- \\
2089\end{array}$ \\
\hline BNU-ESM & 10.2 & 5.3 & 11.0 & 5.5 & 18.5 & 2.5 & 20.8 & 3.2 \\
\hline CanESM2 & - & - & 8.3 & 4.1 & 14.0 & 2.0 & 17.8 & 3.5 \\
\hline HadGEM2-ES & 7.2 & 3.4 & 3.2 & 3.7 & 12.0 & 2.5 & 15.9 & 4.7 \\
\hline IPSL-CM5A-LR & 9.8 & 6.3 & - & - & 16.7 & 3.2 & 19.5 & 3.8 \\
\hline MIROC-ESM & - & - & 12.6 & 4.0 & 15.8 & 3.0 & 19.0 & 3.9 \\
\hline MIROC-ESM-CHEM & - & - & 14.0 & 3.8 & 16.0 & 2.9 & 19.1 & 3.1 \\
\hline Mean $\pm \mathrm{SD}$ & $9.0 \pm 1.6$ & $5.4 \pm 1.0$ & $9.8 \pm 4.3$ & $4.2 \pm 0.7$ & $15.5 \pm 2.3$ & $2.7 \pm 0.4$ & $18.5 \pm 1.7$ & $3.7 \pm 0.6$ \\
\hline $\begin{array}{l}\text { Ensemble mean } \\
\text { climate forcing }\end{array}$ & 8.1 & 5.9 & 11.7 & 4.7 & 16.6 & 2.9 & 19.2 & 3.6 \\
\hline
\end{tabular}
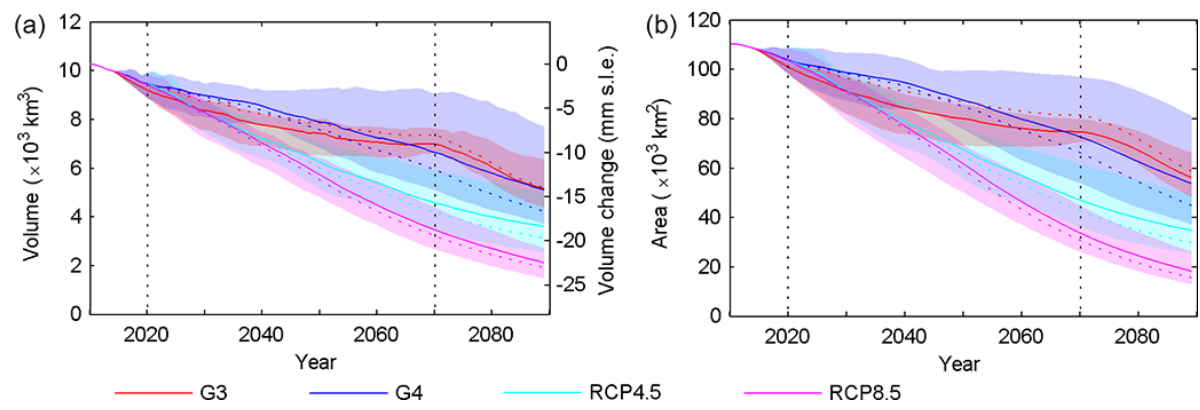

Figure 4. Total glacier volume in HMA (a) and the equivalent sea-level rise assuming an ice density of $900 \mathrm{~kg} \mathrm{~m}^{-3}$ and ocean area of $362 \times 10^{12} \mathrm{~m}^{2}$ and area (b) from 2010 to 2089. The solid curves and shadings are means of individual climate-model-forced simulations and the across-model spread, for colour-coded scenarios. The dashed curves are results using multi-model ensemble mean temperature and precipitation forcing under each scenario.

all close to the means of the individual model-driven mass losses, as are the time-varying loss rates (Fig. 4). Therefore, the geoengineering schemes G3 and G4 help to reduce glacier mass loss in our simulations, and G3 reduces glacier loss more than G4, which is due to stronger temperature cooling effect under G3 (Sect. 4.1.1).

There is a clear increase in volume loss rate under G3 after 2069, when geoengineering is terminated. Comparing the last 15 years of geoengineering (2055-2069) with the first 15 years post-geoengineering (2070-2084) shows annual mean volume loss rate for all the glaciers of $0.17 \% \mathrm{yr}^{-1}$ (referenced to the volume in the year 2010) increases to $1.11 \% \mathrm{yr}^{-1}$, which is higher than the annual mean volume loss rates of $0.54 \% \mathrm{yr}^{-1}$ for RCP4.5 and $0.66 \% \mathrm{yr}^{-1}$ for RCP8.5 in the period 2070-2084. However, the volume loss rate under G4 shows negligible termination effect; annual mean volume loss rates change from 0.73 before to $0.86 \% \mathrm{yr}^{-1}$ after the termination. The glacier volume loss over the post-geoengineering period of 2070-2089 for both G3 and G4 is higher than for either RCP4.5 or RCP8.5 (Table 5). However, by 2070 under both RCP scenarios there is much less glacier ice volume remaining than under $\mathrm{G} 4$, or especially G3. When comparing ice loss rates at comparable total volumes, loss rates with RCP8.5 are similar to those of post geoengineering G3.

As may be expected, glacier area change trends under each climate scenario are similar to the volume change trends (Fig. 4b). We project 53, 41, 27, and $14 \%$ of the area in 2010 remaining in the year 2089 under the G3, G4, RCP4.5, and RCP8.5 scenarios, respectively. 


\subsection{Sub-regional climate and glacier changes}

\subsubsection{Sub-regional temperature and precipitation change}

There are three RGI 5.0 regions in HMA: Central Asia, South Asia West, and South Asia East. They are named as Region 13, 14, and 15 and sub-divided into smaller sub-regions in the RGI 5.0 dataset (Fig. 1). In this section we plot the averages of JJA mean temperatures (Fig. 5) and that of annual solid precipitation at the ELA of every glacier in the start year (Fig. 6) in every sub-region under all the climate scenarios.

Temperatures under RCP8.5 increase at the highest rates (0.053- $\left.0.087^{\circ} \mathrm{C} \mathrm{yr}^{-1}\right)$ among all the scenarios, with temperature increases under RCP4.5 in the range of 0.030 $0.059^{\circ} \mathrm{C} \mathrm{yr}^{-1}$, with its rate decreasing after about the year 2050 as specified greenhouse gas emissions decline. The temperatures rise of $0.030-0.050^{\circ} \mathrm{C} \mathrm{yr}^{-1}$ occurs under $\mathrm{G} 4$ across the sub-regions. Under RCP4.5, RCP8.5, and G4, temperatures increase most slowly in the southeast of the study area (S and E Tibet, C Himalaya, E Himalaya, and Hengduan Shan) and fastest in the northwest (mainly Tien Shan, Hissar Alay, Karakoram, Pamir, and Hindu Kush).

There is no trend in temperature under G3 in the geoengineering period (2020-2069) in all the sub-regions. The temperature cooling projected by G3 as compared with RCP4.5 during $2020-2069$ is about $1.0^{\circ} \mathrm{C}$ in sub-regions of Central Asia, $1.2^{\circ} \mathrm{C}$ in South Asia West, and $0.8^{\circ} \mathrm{C}$ in South Asia East (Fig. 5). After the termination in the year 2069, there is temperature rise of about $1.07-1.65^{\circ} \mathrm{C}$ over the period 2070-2089 relative to the period 2050-2069 under G3. The post-termination temperatures increase the least (about $0.020^{\circ} \mathrm{C} \mathrm{yr}^{-1}$ ) in Karakoram and the most (about $0.046^{\circ} \mathrm{C} \mathrm{yr}^{-1}$ ) in eastern Kunlun. The temperature cooling projected by G4 as compared with RCP4.5 during 2020 2069 is very similar across all the sub-regions: $0.68-0.86^{\circ} \mathrm{C}$.

The annual solid precipitation projected by RCP 8.5 , and to a lesser degree by RCP4.5 and G4, decreases in all the subregions, with the rates larger than $1.5 \mathrm{~mm} \mathrm{yr}^{-1}$ in S and $\mathrm{E}$ Tibet, Hindu Kush, W Himalaya, and the whole of Region 15 (C Himalaya, E Himalaya, Hengduan). There is no obvious trend of solid precipitation projected by G3 in the geoengineering period (2020-2069) in most sub-regions. But after the geoengineering termination under G3 in the year 2069, there is a significant decrease of solid precipitation in $\mathrm{S}$ and E Tibet, Hindu Kush, and the whole of Region 15.

\subsubsection{Sub-regional glacier changes}

Glacier volume changes in the HMA sub-regions are shown in Fig. 7. Glacier volumes in all the sub-regions decrease during the period 2020-2089, with the highest rates under RCP8.5 and the second-highest rates under RCP4.5, as expected. Glacier volumes decrease with lower rates under G3 and G4 in all the sub-regions except $\mathrm{S}$ and $\mathrm{E}$ Tibet, inner
Tibet, and Hengduan Shan, where glacier volumes increase from the year 2020 to about 2040 under G4 and to the end of geoengineering period under G3 (Fig. 7). The glacier volume triples in S and E Tibet and increases by about $56 \%$ in inner Tibet, while increasing slightly in Hengduan Shan in the geoengineering period under G3. The "termination effect" of geoengineering under G3 is significant in most sub-regions.

There are some noticeable difference between means of individual climate-model-forced simulations and the results using multi-model ensemble mean climate forcing (Fig. 7): for example, $\mathrm{S}$ and $\mathrm{E}$ Tibet under all the scenarios, Karakoram under G3, and inner Tibet under G4. This could be because (i) individual model differences in temperature and precipitation forcings are large between ensemble members and their means (especially for the three-model ensemble in G3) in particular sub-regions; (ii) glacier hypsometry differences between regions lead to sensitivity under some combinations of forcing when the ELA change is located around large amounts of ice; and (iii) glacier data inside $\mathrm{S}$ and $\mathrm{E}$ Tibet were measured in the 1970s (Sect. 2) and contain outlines of glacier complexes rather than individual glaciers, which has an impact on the volume estimate because of the nonlinearity of volume-area scaling relationship. Furthermore, the observations offer some support to the model simulations. Liu et al. (2006) and Shi et al. (2006) found that over $40 \%$ of the glaciers in the Gangrigabu Mountains of the $S$ and E Tibetan Plateau have been advancing since the mid-1980s, which is a peculiar phenomena and due to the increase of high precipitation brought by the Indian monsoon.

The across-model spread for each sub-region is not shown for clarity. Note the difference of glacier volume ranges in the panels.

\section{Uncertainties in projections}

Glacier model parameter selection was discussed in Sect. 3.3 and is discussed in more depth by Zhao et al. (2016). In this section we address, and try to estimate, how systematic errors in climate forcing or glacier model parameters cause errors in projections of HMA glacier contributions of sea-level rise.

\subsection{Climate forcing}

There are several uncertainties in climate model forcing used to drive the glacier model in this study. The models are also relatively coarsely gridded, certainly as compared with the vast majority of glaciers, and so differences may be expected between statistically downscaled forcings based on lapse rates that we use here and those produced from highresolution dynamic climate model forcing.

Firstly, only three ESMs participated in G3, while five participated in G4, simply because doing the G3 experiment is difficult and time-consuming to set up. So the ensemble climate projection by $\mathrm{G} 3$ is less robust than that by G4. In many 


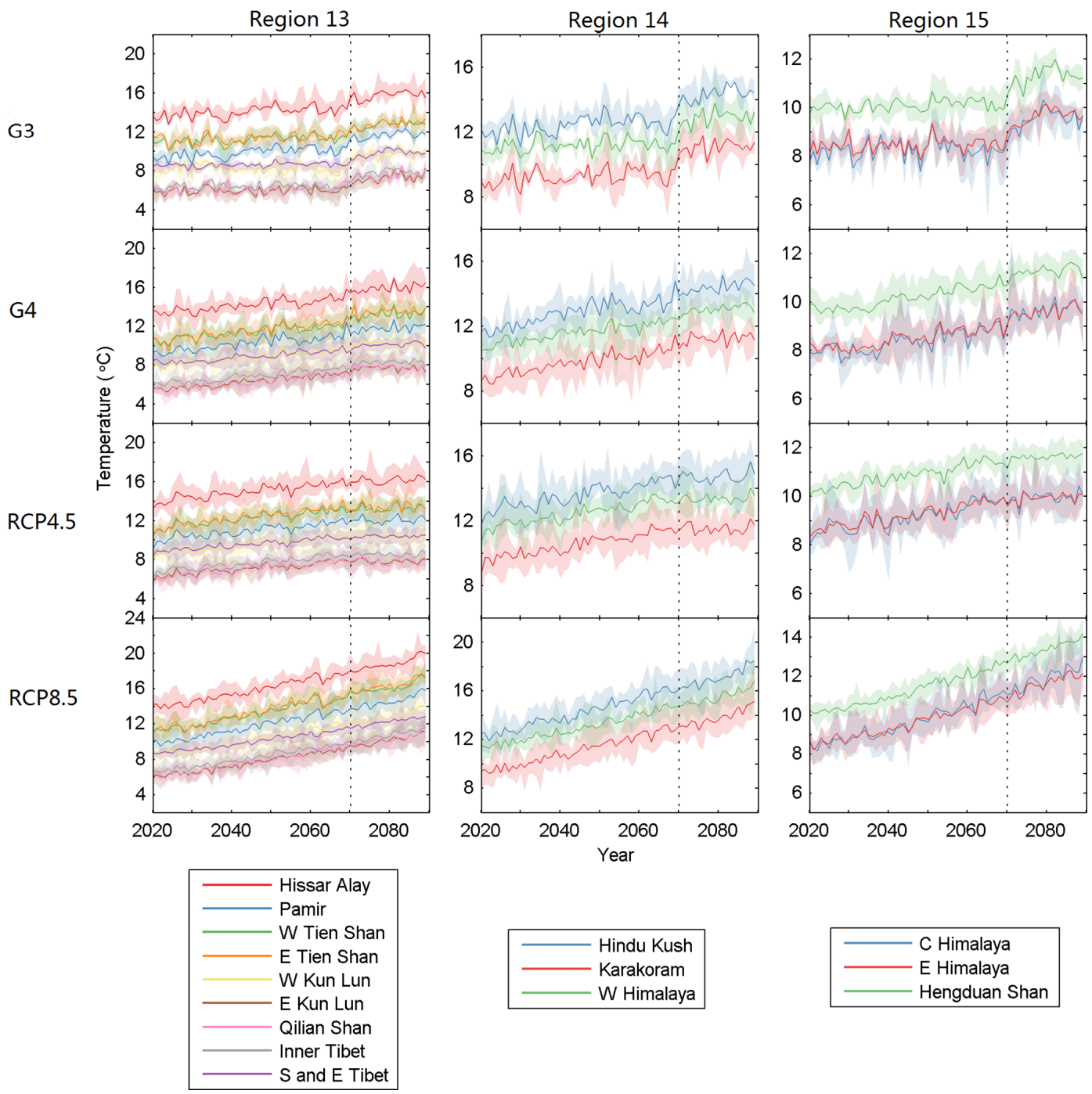

Figure 5. JJA-mean bias-corrected surface air temperature time series from 2010 to 2089 in the sub-regions of Region 13 (left column panels), 14 (middle column panels), and 15 (right column panels) under scenarios by row: G3 (top panels), G4, RCP4.5, and RCP8.5 (bottom panels). Note the different temperature ranges in the panels. The curves and shadings are the ensemble mean and the spread between ensemble members for sub-regions, respectively, which are colour-coded in the legend.

cases it seems that the results from G3 and G4 are statistically similar enough to be combined (Yu et al., 2015; Moore et al., 2015). We tested the differences between RCP8.5, RCP4.5, and G4 using the four models in common (Table 5) and found the glacier responses are significantly different $(p<0.05)$. Although there are too few models in common between G3 and G4, the dominant influence of summer melting to the mass balance across the region (Zhao et al., 2016), and the clear difference in temperature across HMA between G3 and G4 (Figs. 2 and 3) suggests the glacier response in HMA is different between G3 and G4.

Secondly, although the goal of geoengineering schemes is to mitigate temperature rise, it inevitably also alters other important climate parameters, such as precipitation. Simulating change in the Asian monsoon is difficult for climate models under geoengineering since the deep convection involved may also be influenced by chemistry changes in the stratosphere caused by the injected aerosols - most of the ESM models in our study do not have sophisticated aerosol chemistry schemes (though the MIROC-ESM-CHEM model does). Tilmes et al. (2013) showed that changes under the G1 scenario (which specified a much larger shortwave radiation reduction than $\mathrm{G} 3$ or G4) produced a weakening of the Asian monsoon and the hydrological cycle by about $5 \%$. The reductions in solid precipitation (Fig. 3) under RCP8.5 are about one-third of historical levels, and the regions most affected in Region 15 (Fig. 6) are some of those most influenced by monsoon precipitation patterns (Fig. 1). Hence the temperature-driven shift from solid to liquid precipitation is probably more significant than changes in monsoon precip- 


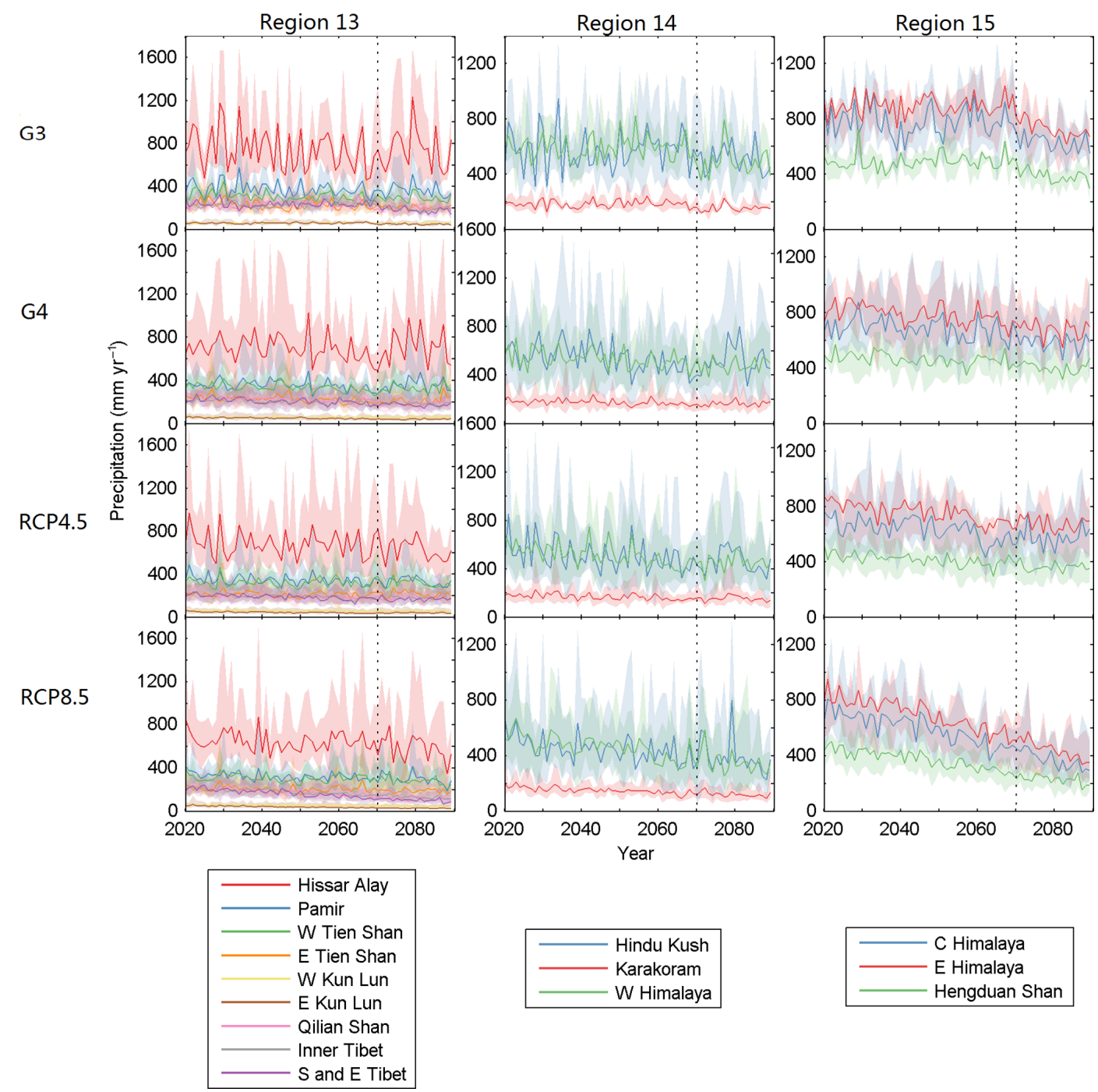

Figure 6. As that for Fig. 5 but for annual solid precipitation on the glacier.

itation suggested by the G1 results discussed by Tilmes et al. (2013).

Thirdly, we note that the distribution of meteorological stations in the study region is very sparse, especially in the northwest of this region (Liu and Chen, 2000). Therefore, both the CRU gridded data and data from model projections that we used in this study may have low accuracy for specific glacier regions. This has also implications for the use of very high resolution dynamic models; one such model simulated air temperatures and down-welling radiative fluxes well, but not wind speed and precipitation, producing unstable results when used with the CLM45 land model that simulated ground temperatures and snow cover (Luo et al., 2013). Explicit glacier atmospheric mass balance modelling (Mölg et al., 2014), a technique based on very high spatial and temporal resolution climate data (hourly and $60 \mathrm{~m}$ ), was used on Zhadang Glacier (Fig. 1, Table 1), with in situ observations available, but not across the general expanse of the glaciated region; this study also noted the importance of wind speed to glacier mass balance in the region influenced by the Indian monsoon. Maussion et al. (2014) demonstrate that $10 \mathrm{~km}$ resolution dynamic modelling of the region can be done successfully and potentially can improve the precipitation modelling over the statistical downscaling methodology we employ here, though to date this is a reanalysis dataset with no prognostic simulations. Zhao et al. $(2014,2016)$ used a $25 \mathrm{~km}$ resolution regional climate model, RegCM3, to drive their simulations of glacier response to scenario A1B. By 2050 under A1B (which is intermediate between RCP4.5 and 8.5 in temperature rise), a sea-level rise equivalent to $9.2 \mathrm{~mm}$ was projected from HMA. In comparison, our estimates are 11.1 and $12.5 \mathrm{~mm}$ for RCP4.5 and RCP8.5, respectively (Fig. 4). 


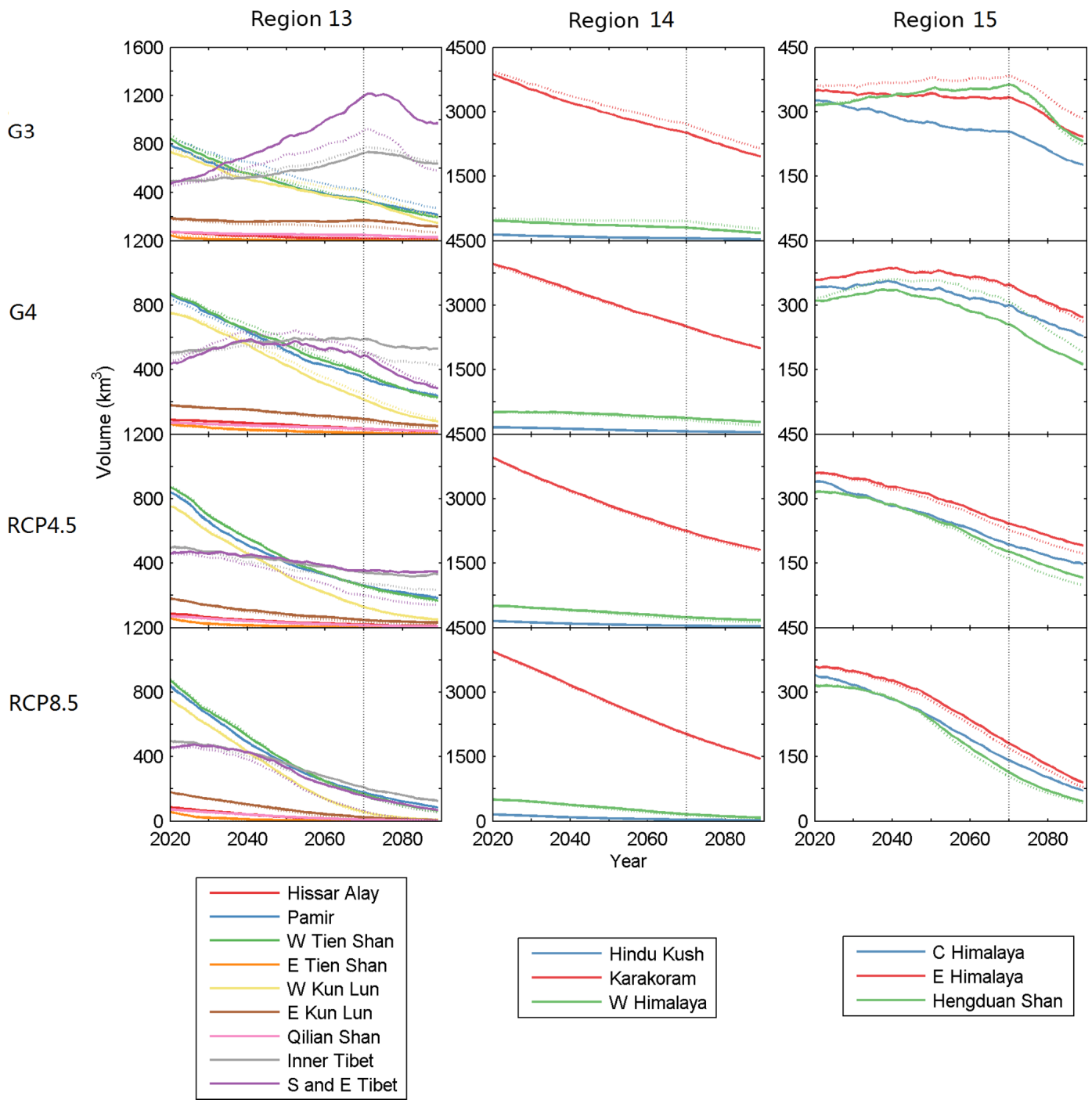

Figure 7. As that for Fig. 5 but for glacier volume (unit: $\mathrm{km}^{3}$ ). The solid curves are means of individual climate-model-forced simulations. The dashed curves are results using multi-model ensemble mean temperature and precipitation forcing under each scenario.

\subsection{Glacier model}

The model we use is not particularly sophisticated; it simply relies on statistical relationships between mass balance and ELA. Compared with the method used in our previous studies (Zhao et al., 2014, 2016), we improved our method here by considering the area response time in the volumearea scaling (Eq. 1), which is more physical. We also allow the glacier area to grow (Sect. 3.1), giving better estimates of glacier area for advancing glaciers. The motivation to use a relatively simple model must be that it simulates the glaciers well given the available data. As previously discussed, there is a shortage of observational data both on glaciers and from climate stations across HMA. In Sect. 3.3 we discussed how the model performs when tested against by the limited data available from satellites and ground measurements; in this section we compare the model against previous simulations of HMA glaciers under climate warming and examine how its weaknesses may affect the reliability of projected mass changes.

Perhaps a strong limitation on the glacier simulation under geoengineering in our model is the lack of response to the changes in shortwave forcing that would be produced under aerosol injection schemes. Van de Berg et al. (2011) showed that Greenland mass balance during the Eemian interglacial could not be explained purely by temperature rise but must also include losses due to changes in the shortwave radiation flux on the ice sheet.

Testing our results for the greenhouse gas scenarios against previous studies, we project glacier volume loss, in equivalent sea-level rise, for all the glaciers from 2010 to 2089 as $18.2 \pm 2.5$ and $22.4 \pm 1.3 \mathrm{~mm}$ under the RCP4.5 
and RCP8.5 scenarios, respectively. The volume change of all the glaciers in HMA over the 21th century estimated by Radić et al. (2014) is about $15 \pm 5 \mathrm{~mm}$ under RCP4.5 and $22 \pm 5 \mathrm{~mm}$ under RCP8.5. Marzeion et al. (2012) estimate about $15.4 \pm 4.5 \mathrm{~mm}$ under RCP4.5 and $18.8 \pm 4.0 \mathrm{~mm}$ under RCP8.5 using projected temperature and precipitation anomalies from an ensemble of 15 CMIP5 climate models. The results projected by our method have higher means than theirs but do not differ significantly.

The across-model uncertainties we plot here (Fig. 4) are smaller than glacier method uncertainties (Sect. 3.3; Zhao et al., 2016). Hence, more mass balance and meterological stations on glaciers across the region, or longer and higherspatial-resolution time series of glacier elevation changes, would better constrain the projected mass losses than simply increasing the number, or resolution, of climate models used in the simulations. That is, the range of mass projections given by the mass balance model with different, but reasonable, choices of data-limited quantities, such as the ELA sensitivity to temperature or the SMB-altitude gradients, is larger than the across-model range for each climate scenario.

Finally we explored the sensitivity to the choice of dataset used to correct model bias in temperatures. The projections using historical temperature from the CRU temperature data and GPCC precipitation suggest that glacier shrinkage from 2010 to 2069 is equivalent to sea-level rise of $9.0 \pm 1.6 \mathrm{~mm}$ (G3), $9.8 \pm 4.3 \mathrm{~mm}(\mathrm{G} 4)$, $15.5 \pm 2.3 \mathrm{~mm}$ (RCP4.5), and $18.5 \pm 1.7 \mathrm{~mm}$ (RCP8.5). In addition, we also ran the simulation using temperature from Berkeley Earth project $\left(1^{\circ} \times 1^{\circ}\right.$ resolution; Rohde et al., 2013; http://berkeleyearth.org/data/). That simulation was done using temperature alone as the glacier driver, so precipitation for each glacier was constant over time. The simulated climate ensemble mean forced volume losses in the period 2010-2069 were $+4 \%$ (G3), $+7 \%$ (G4), $-11 \%$ (RCP4.5), and $-13 \%$ (RCP8.5) different from the results using the CRU dataset.

\section{Summary and conclusion}

We estimate and compare glacier volume loss for glaciers in HMA using a statistical model based on glacier SMB parameterization to the year 2089. We construct temperature and precipitation forcing by using CRU temperature data and GPCC precipitation data before 2013, and projections from 6 Earth system models running RCP4.5 and RCP8.5 and the stratospheric sulfate aerosol injection geoengineering scenarios G3 and G4 with model bias correction and downscaling to a high-resolution spatial grid based on fixed altitudinal lapse rates for temperature and precipitation. In assessing how glaciers respond to geoengineering climates, we consider only across-climate model differences between the scenarios rather than uncertainties in glacier mass caused by errors in the glacier model we use. The projections suggest that glacier shrinkage at the end of the geoengineering period in 2069 is equivalent to sea-level rise of $9.0 \pm 1.6 \mathrm{~mm}(\mathrm{G} 3), 9.8 \pm 4.3 \mathrm{~mm}(\mathrm{G} 4)$, $15.5 \pm 2.3 \mathrm{~mm}$ (RCP4.5), and $18.5 \pm 1.7 \mathrm{~mm}$ (RCP8.5) relative to their volumes in 2010 (Table 5), with 91.8, 96.0, 98.5 , and $99.7 \%$ of glaciers retreating under these scenarios, respectively. There are clear increases in temperature and glacier volume loss rate under G3 after 2069, when geoengineering is terminated, which is higher than the rate under RCP8.5. But the termination effect under G4 is negligible. Glacier volumes decrease in most sub-regions under all the scenarios, while they increase in inner Tibet, S and E Tibet, and Hengduan Shan from the year 2020 to about 2040 under G4 and to the end of geoengineering period under G3.

Although G3 keeps the average temperature from increasing in the geoengineering period, G3 only slows glacier shrinkage by about $50 \%$ relative to losses from RCP8.5. Approximately $72 \%$ of glaciated area remains at 2069 under G3, as compared with about $30 \%$ for RCP8.5. The reason for the G3 losses is likely to be that the glaciers in HMA are not in equilibrium with present-day climate, so simply stabilizing temperatures at early-21st-century levels does not preserve them. To do that would require significant cooling, perhaps back to early-20th-century levels. Achieving that cooling by sulfate aerosol injection may not be possible. The $5 \mathrm{Tg}$ of $\mathrm{SO}_{2}$ per year specified in $\mathrm{G} 4$ is about the same loading as a 1991 Mount Pinatubo volcanic eruption every 4 years (Bluth et al., 1992). G3 requires increasing rates of injection, to $9.8 \mathrm{Tg}$, for the BNU-ESM in 2069. As aerosol loading increases, its efficacy decreases as particles coalesce and fall out of the stratosphere faster, while also becoming radiatively less effective (Niemeier and Timmreck, 2015). This effect is so strong that it appears unfeasible to use sulfate aerosols to completely eliminate warming from scenarios such as RCP8.5. Greenhouse gas emissions would require very drastic reduction from present levels, and net negative emissions within the next few decades, to limit global temperature rise to 1.5 or $2{ }^{\circ} \mathrm{C}$ (Rogelj et al., 2015). If such targets are met, then it is conceivable that plausible quantities of sulfate aerosol geoengineering may be able to maintain 2020 temperatures throughout the 21 st century. Our simulations suggest that, even if this politically very difficult combination of drastic emission cuts and quite aggressive sulfate aerosol geoengineering were done, the disappearance of about one-third of the glaciated area in HMA by 2069 still could not be avoided.

Data availability. We used the following published datasets: Randolph Glacier Inventory 5.0 (Arendt et al., 2015; http://www. glims.org/RGI/); Shuttle Radar Topography Mission (SRTM) version 4.1 (Jarvis et al., 2008; http://srtm.csi.cgiar.org); Climatic Research Unit Time-Series (CRU TS) 3.24 (Harris et al., 2014; https: //crudata.uea.ac.uk/cru/data/hrg); and Global Precipitation Climatology Centre (GPCC) Total Full V7 (Becker et al., 2013; https:// 
www.esrl.noaa.gov/psd/data/gridded/data.gpcc.html). Climate forcing data under RCP4.5 and RCP8.5 can be downloaded from the IPCC Data Distribution Centre (http://www.ipcc-data.org/sim/ gcm_monthly/AR5/Reference-Archive.html). Climate forcing data under GeoMIP scenarios (G3 and G4) are from Earth System Grid Federation (https://esgf-node.llnl.gov/), or contact Ben Kravitz (ben.kravitz@pnnl.gov).

Competing interests. The authors declare that they have no conflict of interest.

Acknowledgements. We thanks two anonymous referees for very constructive critiques of the paper, all participants of the Geoengineering Model Intercomparison Project and their model development teams, CLIVAR/WCRP Working Group on Coupled Modelling for endorsing GeoMIP, and the scientists managing the Earth System Grid Federation data nodes who have assisted in making GeoMIP output available. This study is supported by the National Key Science Program for Global Change Research (2015CB953601), National Natural Science Foundation of China (nos. 41530748, 41506212, 40905047), and National Key Basic Research Program of China (2016YFA0602701).

Edited by: B. Kravitz

Reviewed by: two anonymous referees

\section{References}

Applegate, P. J. and Keller, K.: How effective is albedo modification (solar radiation management geoengineering) in preventing sealevel rise from the Greenland Ice Sheet?, Environ. Res. Lett., 10, 084018, https://doi.org/10.1088/1748-9326/10/8/084018, 2015.

Arendt, A., Bliss, A., Bolch, T., Cogley, J. G., Gardner, A. S., Hagen, J.-O., Hock, R., Huss, M., Kaser, G., Kienholz, C., Pfeffer, W. T., Moholdt, G., Paul, F., Radić, V., Andreassen, L., Bajracharya, S., Barrand, N. E., Beedle, M., Berthier, E., Bhambri, R., Brown, I., Burgess, E., Burgess, D., Cawkwell, F., Chinn, T., Copland, L., Davies, B., De Angelis, H., Dolgova, E., Earl, L., Filbert, K., Forester, R., Fountain, A. G., Frey, H., Giffen, B., Glasser, N., Guo, W. Q., Gurney, S., Hagg, W., Hall, D., Haritashya, U. K., Hartmann, G., Helm, C., Herreid, S., Howat, I., Kapustin, G., Khromova, T., König, M., Kohler, J., Kriegel, D., Kutuzov, S., Lavrentiev, I., LeBris, R., Liu, S. Y., Lund, J., Manley, W., Marti, R., Mayer, C., Miles, E. S., Li, X., Menounos, B., Mercer, A., Mölg, N., Mool, P., Nosenko, G., Negrete, A., Nuimura, T., Nuth, C., Pettersson, R., Racoviteanu, A., Ranzi, R., Rastner, P., Rau, F., Raup, B., Rich, J., Rott, H., Sakai, A., Schneider, C., Seliverstov, Y., Sharp, M., Sigursson, O., Stokes, C., Way, R. G., Wheate, R., Winsvold, S., Wolken, G., Wyatt, F., and Zheltyhina, N.: Randolph Glacier Inventory - A Dataset of Global Glacier Outlines: Version 5.0, GLIMS Technical Report, Global Land Ice Measurements from Space, Digital media, Boulder, CO, http://www.glims.org/RGI/ (last access: 31 May 2017), 2015.

Arora, V. K., Scinocca, J. F., Boer, G. J., Christian, J. R., Denman, K. L., Flato, G. M., Kharin, V. V., Lee, W. G., and Merryfield,
W. J.: Carbon emission limits required to satisfy future representative concentration pathways of greenhouse gases, Geophys. Res. Lett., 38, L05805, https://doi.org/10.1029/2010GL046270, 2011.

Azam, M. F., Wagnon, P., Ramanathan, A., Vincent, C., Sharma, P., Arnaud, Y., Linda, A., Pottakkal, G. J., Chevallier, P., Singh, V. B., and Berthier, E.: From balance to imbalance: a shift in the dynamic behaviour of Chhota Shigri Glacier (Western Himalaya, India), J. Glaciol., 58, 315-324, 2012.

Bahr, D. B., Meier, M., and Peckham, S.: The physical basis of glacier volume-area scaling, J. Geophys. Res., 102, 355-362, 1997.

Becker, A., Finger, P., Meyer-Christoffer, A., Rudolf, B., Schamm, K., Schneider, U., and Ziese, M.: A description of the global land-surface precipitation data products of the Global Precipitation Climatology Centre with sample applications including centennial (trend) analysis from 1901-present, Earth Syst. Sci. Data, 5, 71-99, https://doi.org/10.5194/essd-5-71-2013, 2013.

Bluth, G. J. S., Doiron, S. D., Schnetzler, C. C., Krueger, A. J., and Walter, L. S.: Global tracking of the $\mathrm{SO}_{2}$ clouds from the June 1991 Mount Pinatubo eruptions, Geophys. Res. Lett., 19, 151-154, 1992.

Collins, W. J., Bellouin, N., Doutriaux-Boucher, M., Gedney, N., Halloran, P., Hinton, T., Hughes, J., Jones, C. D., Joshi, M., Liddicoat, S., Martin, G., O’Connor, F., Rae, J., Senior, C., Sitch, S., Totterdell, I., Wiltshire, A., and Woodward, S.: Development and evaluation of an Earth-System model - HadGEM2, Geosci. Model Dev., 4, 1051-1075, https://doi.org/10.5194/gmd-4-10512011, 2011.

Du, J., He, Y., Li, S., Wang, S., Niu, H., Xin, H., and Pu, T.: Mass balance and near-surface ice temperature structure of Baishui Glacier No. 1 in Mt. Yulong, J. Geogr. Sci., 23, 668-678, 2013.

Dufresne, J.-L., Foujols, M.-A., Denvil, S., Caubel, A., Marti, O., Aumont, O., Balkanski, Y., Bekki, S., Bellenger, H., Benshila, R., Bony, S., Bopp, L., Braconnot, P., Brockmann, P., Cadule, P., Cheruy, F., Codron, F., Cozic, A., Cugnet, D., de Noblet, N., Duvel, J.-P., Ethe, C., Fairhead, L., Fichefet, T., Flavoni, S., Friedlingstein, P., Grandpeix, J.-Y., Guez, L., Guilyardi, E., Hauglustaine, D., Hourdin, F., Idelkadi, A., Ghattas, J., Joussaume, S., Kageyama, M., Krinner, G., Labetoulle, S., Lahellec, A., Lefebvre, M.-P., Lefevre, F., Levy, C., Li, Z. X., Lloyd, J., Lott, F., Madec, G., Mancip, M., Marchand, M., Masson, S., Meurdesoif, Y., Mignot, J., Musat, I., Parouty, S., Polcher, J., Rio, C., Schulz, M., Swingedouw, D., Szopa, S., Talandier, C., Terray, P., Viovy, N., and Vuichard, N.: Climate change projections using the IPSL-CM5 earth system model: From CMIP3 to CMIP5, Clim. Dynam., 40, 2123-2165, 2013.

Fujita, K. and Ageta, Y.: Effect of summer accumulation on glacier mass balance on the Tibetan Plateau revealed by mass-balance model, J. Glaciol., 46, 244-252, https://doi.org/10.3189/172756500781832945, 2000.

Fujita, K. and Nuimura, T.: Spatially heterogeneous wastage of Himalayan glaciers, P. Natl. Acad. Sci. USA, 108, 14011-14014, https://doi.org/10.1073/pnas.1106242108, 2011.

Gao, X., Shi, Y., Zhang, D., and Giorgi, F.: Climate change in China in the 21 st century as simulated by a high resolution regional climate model, Chin. Sci. Bull., 57, 1188-1195, 2012.

Gardner, A. S., Moholdt, G., Cogley, J. G., Wouters, B., Arendt, A. A., Wahr, J., Berthier, E., Hock, R., Pfeffer, W. T., Kaser, 
G., Ligtenberg, S. R. M., Bolch, T., Sharp, M. J., Hagen, J. O., van den Broeke, M. R., and Frank, P.: A reconciled estimate of glacier contributions to sea level rise: 2003 to 2009, Science, 340, 852-857, 2013.

Guo, W., Liu, S., Xu, J., Wu, L., Shangguan, D., Yao, X., Wei, J., Bao, W., Yu, P., Liu, Q., and Jiang, Z.: The second Chinese glacier inventory: data, methods and results, J. Glaciol., 61, 357372, https://doi.org/10.3189/2015JoG14J209, 2015.

Harris, I., Jones, P. D., Osborn, T. J., and Lister, D. H.: Updated high-resolution grids of monthly climatic observations - the CRU TS3.10 Dataset, Int. J. Climatol., 34, 623-642, https://doi.org/10.1002/joc.3711, 2014 (data available at: https: //crudata.uea.ac.uk/cru/data/hrg, last access: 31 May 2017).

Irvine, P. J., Lunt, D. J., Stone, E. J., and Ridgwell, A. J.: The fate of the Greenland Ice Sheet in a geoengineered, high $\mathrm{CO}_{2}$ world, Environ. Res. Lett., 4, 045109, https://doi.org/10.1088/17489326/4/4/045109, 2009.

Irvine, P. J., Sriver, R. L., and Keller, K.: Tension between reducing sea-level rise and global warming through solar radiation management, Nat. Clim. Change, 2, 97-100, 2012.

Jarvis, A., Reuter, H. I., Nelson, A., and Guevara, E.: Hole-filled seamless SRTM data V4, International Centre for Tropical Agriculture (CIAT), available at: http://srtm.csi.cgiar.org (last access: 23 May 2017), 2008.

Ji, D., Wang, L., Feng, J., Wu, Q., Cheng, H., Zhang, Q., Yang, J., Dong, W., Dai, Y., Gong, D., Zhang, R.-H., Wang, X., Liu, J., Moore, J. C., Chen, D., and Zhou, M.: Description and basic evaluation of Beijing Normal University Earth System Model (BNU-ESM) version 1, Geosci. Model Dev., 7, 20392064, https://doi.org/10.5194/gmd-7-2039-2014, 2014.

Johannesson, T., Raymond, C., and Waddington, E.: Time-scale for adjustment of glaciers to changes in mass balance, J. Glaciol., 35, 355-369, 1989.

Jones, A., Haywood, J. M., Alterskjaer, K., Boucher, O., Cole, J. N. S., Curry, C. L., Irvine, P. J., Ji, D., Kravitz, B., Kristjánsson, J. E., Moore, J. C., Niemeier, U., Robock, A., Schmidt, H., Singh, B., Tilmes, S., Watanabe, S., and Yoon, J.-H.: The impact of abrupt suspension of solar radiation management (termination effect) in experiment G2 of the Geoengineering Model Intercomparison Project (GeoMIP), J. Geophys. Res.-Atmos., 118, $9743-$ 9752, 2013.

Kravitz, B., A. Robock, O. Boucher, H. Schmidt, K. E. Taylor, G. Stenchikov, and M. Schulz, The Geoengineering Model Intercomparison Project (GeoMIP), Atmos. Sci. Lett., 12(2), 162167, 2011.

Liu, S., Shangguan, D., Ding, Y., Han, H., Xie, C., Zhang, Y., Li, J., Wang, J., and Li, G.: Glacier changes during the past century in the Gangrigabu mountains, southeast Qinghai-Xizang (Tibetan) Plateau, China, Ann. Glaciol., 43, 187-193, 2006.

Liu, X. and Chen, B.: Climatic warming in the Tibetan Plateau during recent decades, Int. J. Climatol., 20, 1729-1742, 2000.

Luo, L. H., Zhang, Y. N., Zhou, J., Pan, X. D., and Sun, W. J., Simulation and Application of the Land Surface Model CLM Driven by WRF in the Tibetan Plateau, J. Glaciol. Geocryol., 35, 553564, 2013.

Marzeion, B., Jarosch, A. H., and Hofer, M.: Past and future sealevel change from the surface mass balance of glaciers, The Cryosphere, 6, 1295-1322, https://doi.org/10.5194/tc-6-12952012, 2012.
Maussion, F., Scherer, D., Mölg, T., Collier, E., Curio, J., and Finkelnburg, R.: Precipitation seasonality and variability over the Tibetan Plateau as Resolved by the High Asia Reanalysis, J. Climate, 27, 1910-1927, 2014.

McCusker, K. E., Battisti, D. S., and Bitz, C. M.: Inability of stratospheric sulfate aerosol injections to preserve the West Antarctic Ice Sheet, Geophys. Res. Lett., 42, 4989-4997, 2015.

Mölg, T., Maussion, F., Yang, W., and Scherer, D.: The footprint of Asian monsoon dynamics in the mass and energy balance of a Tibetan glacier, The Cryosphere, 6, 1445-1461, https://doi.org/10.5194/tc-6-1445-2012, 2012.

Mölg, T., Maussion, F., and Scherer, D.: Mid-latitude westerlies as a driver of glacier variability in monsoonal High Asia, Nat. Clim. Change, 4, 68-73, 2014.

Moore, J. C., Jevrejeva, S., and Grinsted, A.: Efficacy of geoengineering to limit 21 st century sea-level rise, P. Natl. Acad. Sci USA, 107, 15699-15703, 2010.

Moore, J. C., Grinsted, A., Zwinger, T., and Jevrejeva, S.: Semiempirical and process-based global sea level projections, Rev. Geophys., 51, 1-39, 2013.

Moore, J. C., Grinsted, A., Guo, X., Yu, X., Jevrejeva, S., Rinke, A., Cui, X., Kravitz, B., Lenton, A., Watanabe, S., and Ji, D.: Atlantic hurricane surge response to geoengineering, P. Natl. Acad. Sci. USA, 112, 13794-13799, https://doi.org/10.1073/pnas.1510530112, 2015.

Niemeier, U. and Timmreck, C.: What is the limit of climate engineering by stratospheric injection of $\mathrm{SO}_{2}$ ?, Atmos. Chem. Phys., 15, 9129-9141, https://doi.org/10.5194/acp-159129-2015, 2015.

Nuimura, T., Sakai, A., Taniguchi, K., Nagai, H., Lamsal, D., Tsutaki, S., Kozawa, A., Hoshina, Y., Takenaka, S., Omiya, S., Tsunematsu, K., Tshering, P., and Fujita, K.: The GAMDAM glacier inventory: a quality-controlled inventory of Asian glaciers, The Cryosphere, 9, 849-864, https://doi.org/10.5194/tc9-849-2015, 2015.

Pu, J. T. Y., Duan, K., Sakai, A., Fujita, K., and Matsuda, Y.: Mass balance of the Qiyi Glacier in the Qilian Mountains: a new observation, J. Glaciol. Geocryol., 27, 199-204, 2005.

Radic, V., Hock, R., and Oerlemans, J.: Analysis of scaling methods in deriving future volume evolutions of valley glaciers, J. Glaciol., 54, 601-612, 2008.

Radić, V., Bliss, A., Beedlow, A. C., Hock, R., Miles, E., and Cogley, J. G.: Regional and global projections of the 21st century glacier mass changes in response to climate scenarios from GCMs, Clim. Dynam., 42, 37-58, 2014.

Ricke, K. L., Morgan, M. G., and Allen, M. R.: Regional climate response to solar-radiation management, Nat. Geosci., 3, 537541, 2010.

Rogelj, J., Luderer, G., Pietzcker, R.C., Kriegler, E., Schaeffer, M., Krey, V., and Riahi, K.: Energy system transformations for limiting end-of-century warming to below $1.5^{\circ} \mathrm{C}$, Nat. Clim. Change, 5, 519-527, https://doi.org/10.1038/nclimate2572, 2015.

Rohde, R., Muller, R. A., Jacobsen, R., Muller, E., Perlmutter, S., Rosenfeld, A., Wurtele, J., Groom D., and Wickham, C.: A new estimate of the average Earth surface land temperature spanning 1753 to 2011, Geoinfor. Geostat.-An Overview, 1, 1000101, https://doi.org/10.4172/2327-4581.1000101, 2013 
Rupper, S. and Roe, G.: Glacier changes and regional climate: a mass and energy balance approach, J. Climate, 21, 5384-5401, 2008.

Shi, Y., Liu, S., Shangguan, D., Li, D., Ye, B., and Shen, Y.: Two Peculiar Phenomena of Climatic and Glacier Variations in the Tibetan Plateau, Adv. Clim. Change Res., 2, 154-160, 2006.

Taylor, K. E., Stouffer, R. J., and Meehl, G. A.: An overview of CMIP5 and the experiment design, B. Am. Meteorol. Soc., 93, 485-498, 2012.

Tilmes, S., Fasullo, J., Lamarque, J.-F., Marsh, D. R., Mills, M., Alterskjaer, K., Muri, H., Kristjansson, J. E., Boucher, O., Schulz, M., Cole, J. N. S., Curry, C. L., Jones, A., Haywood, J., Irvine, P. J., Ji, D., Moore, J. C., Karam, D. B., Kravitz, B., Rasch, P. J., Singh, B., Yoon, J.-H., Niemeier, U., Schmidt, H., Robock, A., Yang, S., and Watanabe, S.: The hydrological impact of geo-engineering in the Geoengineering Model Intercomparison Project (GeoMIP), J. Geophys. Res., 118, 11036-11058, 2013.

van de Berg, W. J., van den Broeke, M., Ettema, J., van Meijgaard, E., and Kaspar, F.: Significant contribution of insolation to Eemian melting of the Greenland ice sheet, Nat. Geosci., 4, 679-683, 2011.

Wagnon, P., Linda, A., Arnaud, Y., Kumar, R., Sharma, P., Vincent, C., Pottakkal, G. J., Berthier, E., Ramanathan, A., Hasnain, S. I., and Chevallier, P.: Four years of mass balance on Chhota Shigri Glacier, Himachal Pradesh, India, a new benchmark glacier in the Western Himalaya, J. Glaciol., 53, 603-610, 2007.

Wang, S., Pu, J., and Wang, N.: Study of Mass Balance and Sensibility to Climate Change of Qiyi Glacier in Qilian Mountains, J. Glaciol. Geocryol., 33, 1214-1221, 2011.

Watanabe, S., Hajima, T., Sudo, K., Nagashima, T., Takemura, T., Okajima, H., Nozawa, T., Kawase, H., Abe, M., Yokohata, T., Ise, T., Sato, H., Kato, E., Takata, K., Emori, S., and Kawamiya, M.: MIROC-ESM 2010: model description and basic results of CMIP5-20c3m experiments, Geosci. Model Dev., 4, 845-872, https://doi.org/10.5194/gmd-4-845-2011, 2011.

WGMS: Glacier Mass Balance Bulletin No. 1 (1988-1989), edited by: Haeberli, W. and Herren, E., IAHS (ICSI)/UNEP/UNESCO, World Glacier Monitoring Service, Zurich, 1991.

WGMS: Glacier Mass Balance Bulletin No. 2 (1990-1991), edited by: Haeberli, W., Herren, E., and Hoelzle, M., IAHS (ICSI)/UNEP/UNESCO, World Glacier Monitoring Service, Zurich, 1993.

WGMS: Glacier Mass Balance Bulletin No. 3 (1992-1993), edited by: Haeberli, W., Hoelzle, M., and Bosch, H., IAHS (ICSI)/UNEP/UNESCO, World Glacier Monitoring Service, Zurich, 1994.

WGMS: Glacier Mass Balance Bulletin No. 4 (1994-1995), edited by: Haeberli, W., Hoelzle, M., and Suter, S., IAHS (ICSI)/UNEP/UNESCO, World Glacier Monitoring Service, Zurich, 1996.

WGMS: Glacier Mass Balance Bulletin No. 5 (1996-1997), edited by: Haeberli, W., Hoelzle, M., and Frauenfelder, R., IAHS (ICSI)/UNEP/UNESCO, World Glacier Monitoring Service, Zurich, 1999.

WGMS: Glacier Mass Balance Bulletin No. 6 (1998-1999), edited by: Haeberli, W., Frauenfelder, R., and Hoelzle, M., IAHS (ICSI)/UNEP/UNESCO/WMO, World Glacier Monitoring Service, Zurich, 2001.
WGMS: Glacier Mass Balance Bulletin No. 7 (2000-2001), edited by: Haeberli, W., Frauenfelder, R., Hoelzle, M., and Zemp, M., IAHS (ICSI)/UNEP/UNESCO/WMO, World Glacier Monitoring Service, Zurich, 2003.

WGMS: Glacier Mass Balance Bulletin No. 8 (2002-2003), edited by: Haeberli, W., Noetzli, J., Zemp, M., Baumann, S., Frauenfelder, R., and Hoelzle, M., IUGG (CCS)/UNEP/UNESCO/WMO, World Glacier Monitoring Service, Zurich, 2005.

WGMS: Glacier Mass Balance Bulletin No. 9 (2004-2005), edited by: Haeberli, W., Hoelzle, M., and Zemp, M., ICSU (FAGS)/IUGG (CCS)/UNEP/UNESCO/WMO, World Glacier Monitoring Service, Zurich, 2007.

WGMS: Glacier Mass Balance Bulletin No. 10 (20062007), edited by: Haeberli, W., Gärtner-Roer, I., Hoelzle, M., Paul, F., and Zemp, M., ICSU (WDS)/IUGG (IACS)/UNEP/UNESCO/WMO, World Glacier Monitoring Service, Zurich, 2009.

WGMS: Glacier Mass Balance Bulletin No. 11 (2008-2009), edited by: Zemp, M., Nussbaumer, S. U., Gärtner-Roer, I., Hoelzle, M., Paul, F., and Haeberli, W., ICSU (WDS)/IUGG (IACS)/UNEP/UNESCO/WMO, World Glacier Monitoring Service, Zurich, 2011.

WGMS: Glacier Mass Balance Bulletin No. 12 (2010-2011), edited by: Zemp, M., Nussbaumer, S. U., Naegeli, K., Gärtner-Roer, I., Paul, F., Hoelzle, M., and Haeberli, W., ICSU (WDS)/IUGG (IACS)/UNEP/UNESCO/WMO, World Glacier Monitoring Service, Zurich, 2013.

Yang, W., Yao, T., Guo, X., Zhu, M., Li, S., and Kattel, D. B.: Different region climate regimes and topography affect the changes in area and mass balance of glaciers on the north and south slopes of the same glacierized massif (the West Nyainqentanglha Range, Tibetan Plateau), J. Hydrol., 495, 64-73, 2013 a.

Yang, W., Yao, T., Guo, X., Zhu, M., Li, S., and Kattel, D. B.: Mass balance of a maritime glacier on the southeast Tibetan Plateau and its climatic sensitivity, J. Geophys. Res.-Atmos., 118, 95799594, 2013b.

Yao, T., Thompson, L., Yang, W., Yu, W., Gao, Y., Guo, X., Yang, X., Zhao, H., Duan, K., Xu, B., Pu, J., Lu, A., Qin, D. H., Xiang, Y., Kattel, D. B., and Joswiak, D.: Different glacier status with atmospheric circulations in Tibetan Plateau and surroundings, Nat. Clim. Change, 2, 663-667, https://doi.org/10.1038/NCLIMATE1580, 2012.

Yu, W., Yao, T., Kang, S., Pu, J., Yang, W., Gao, T., Zhao, H., Zhou, H., Li, S., Wang, W., and Ma, L.: Different region climate regimes and topography affect the changes in area and mass balance of glaciers on the north and south slopes of the same glacierized massif (the West Nyainqentanglha Range, Tibetan Plateau), J. Hydrol., 495, 64-73, 2013.

Yu, X., Moore, J. C., Cui, X., Rinke, A., Ji, D., Kravitz, B., and Yoon, J.-H.: Impacts, effectiveness and regional inequalities of the GeoMIP G1 to G4 solar radiation management scenarios, Global Planet. Change, 129, 10-22, 2015.

Zhang, H., Li, Z., Wang, P., and Huai, B.: Variation of Haxilegen No. 51 Glacier at the Headwater of Kuytun River in Tianshan Mountains and Its Response to Climate Change, Arid Zone Res., 32, 88-93, 2015.

Zhang, J., He, X., Ye, B., and Wu, J.: Recent Variation of Mass Balance of the Xiao Dongkemadi Glacier in the Tanggula Range 
and its influencing factors, J. Glaciol. Geocryol., 35, 263-271, 2013.

Zhao, L., Ding, R., and Moore, J. C.: Glacier volume and area change by 2050 in high mountain Asia, Global Planet. Change, 122, 197-207, 2014.

Zhao, L., Ding, R., and Moore, J. C.: The High Mountain Asia glacier contribution to sea level rise from 2000 to 2050, Ann. Glaciol., 71, 223-231, 2016.
Zhou, G., Yao, T., Kang, S., Pu, J., Tian, L., and Yang, W.: Mass balance of the Zhadang Glacier in the central Tibetan Plateau, J. Glaciol. Geocryol., 29, 360-365, 2007. 